\title{
18. DISTRIBUTION PATTERNS OF NEOGENE BENTHIC FORAMINIFERS IN SITES 717, 718, AND 719 (LEG 116) ${ }^{1}$
}

\author{
Silvia Iaccarino ${ }^{2}$ and Franca Proto Decima ${ }^{3}$
}

\begin{abstract}
Benthic foraminifers were examined from turbiditic sequences at Sites 717,718 , and 719 . Three assemblages, 1 , 2,3 , were identified and are interpreted as reflecting different bathymetric environments. Based on the distribution patterns of these assemblages, six paleontological intervals (a to f) were distinguished and correlated to the lithostratigraphic units and calcareous nannofossil biostratigraphy and biochronology. This relationship indicated three signals of climatic deterioration, the first in the late Pliocene (around $2.42 \mathrm{Ma}$ ) and two others in the Pleistocene (younger than $1.59 \mathrm{Ma}$ and $0.93 \mathrm{Ma}$ ).
\end{abstract}

\section{INTRODUCTION}

This paper investigates Neogene benthic foraminifers, recovered at three sites drilled during Ocean Drilling Program (ODP) Leg 116 on the distal part of the Bengal Fan in the Indian Ocean (Fig.1). Sites 717, 718, and 719 were drilled in water depths close to the present carbonate compensation depth (CCD) (deeper than $4500 \mathrm{~m}$ ); the sediments are mainly mud and silt turbidites.

Site 717 is located at $0^{\circ} 55.785^{\prime} \mathrm{S}, 81^{\circ} 23.408^{\prime} \mathrm{E}, 800 \mathrm{~km}$ south of Sri Lanka and $200 \mathrm{~km}$ northwest of the Afanasiy Nikitin Seamount group. The post-deformation sedimentary sequence, here at its maximum thickness, ranges from Holocene to late Miocene (CN9). Three holes (A, B, C) were drilled at Site 717 in a water depth of $4765 \mathrm{~m}$, but only Holes 717B and 717C are investigated as regards benthic foraminifers. The lithostratigraphic units recognized in Site 717 are Units I, II, III, IVA, IVB, IVC, IVD, VA, and VB (Shipboard Scientific Party, 1989a).

Site 718 is located at $1^{\circ} 01.252^{\prime} \mathrm{S}, 81^{\circ} 24.065^{\prime} \mathrm{E}$ on the faulted block immediately south of the block drilled at Sites 717 and 719. The site was drilled at a water depth of $4731 \mathrm{~m}$. On the whole, recovery was very poor, except for the interval characterized by mud turbidites. The recovered stratigraphic section ranges from Holocene to early Miocene (well below the highest recorded occurrence of Helicosphaera ampliaperta) (Gartner, this volume). Four lithologic units were recognized; (Units I, II, III-IV, and VA-VB; Shipboard Scientific Party, 1989b).

Site 719 is very close to Site 717 (within about $0.6 \mathrm{~km}$ ). It is located at $0^{\circ} 57.646^{\prime} \mathrm{S}, 81^{\circ} 23.967^{\prime} \mathrm{E}$ and was drilled in a water depth of $4737 \mathrm{~m}$. The recovered stratigraphic section ranges from late Quaternary to late Miocene (CN15 to CN9) (Gartner, this volume). The sedimentary section corresponds closely to that of Site 717, and Units I, II, III, IVA, IVB, IVC, IVD, and V were recognized (Shipboard Scientific Party, 1989c).

The lithostratigraphic units distinguished in the sedimentary sequence of the three sites (Cochran, Stow, et al., 1989), with different thicknesses and minor differences in lithology between them, may be summarized as follows:

Unit I: muds, mud turbidites, and pelagic or calcareous clays

\footnotetext{
${ }^{1}$ Cochran, J. R., Stow, D.A.V., et al., 1990. Proc. ODP, Sci. Results, 116: College Station, TX, U.S.A. (Ocean Drilling Program).

2 Istituto di Geologia, Parma University, Italy. Italy.

${ }^{3}$ Dipartimento di Geologia, Paleontologia e Geofisica, Padova University,
}

Unit II: micaceous silt turbidites with thin interbedded muds, and calcareous clays

Unit III: biogenic mud turbidites and mud turbidites with thin interbedded pelagic clays

Unit IV: silt turbidites with thin intercalations of muds and mud turbidites (Subunit IVA), mud turbidites with interbedded pelagic clays (Subunit IVB), silt and silt-to-mud turbidites (Subunit IVC), and mud turbidites with interbedded pelagic clays (Subunit IVD)

Unit V: silt and silt-mud turbidites with thin sporadic interbeds of mud turbidites and pelagic clays (Subunit VA), and silt and silt-mud turbidites, biogenic mud turbidites, and pelagic clays (Subunit VB).

Planktonic foraminifers are generally rare and poorly preserved. They are common in the topmost surface sediments only, where they are strongly affected by dissolution, as indicated by abundant fragmented tests and etched specimens. This sporadic occurrence results in very little biostratigraphic information (Cochran, Stow, et al., 1989). Therefore, in this study the time-stratigraphic framework is based on calcareous nannofossils (Gartner, this volume).

Benthic foraminifers are scattered throughout the redeposited sediments, except for the interval characterized by biogenic turbidites (Unit III) where they constitute the bulk of the residue $>63 \mu \mathrm{m}$ and $<150 \mu \mathrm{m}$.

\section{SAMPLING AND METHODS}

Sampling, initially planned for one sample per core section, was further limited by the scarcity of favorable fossiliferous lithologies within the turbiditic sequence and by recovery. Thus, sample spacing is remarkably irregular (Table 1). The coarsest sequences are poorly sampled, whereas the finest are more closely sampled. According to lithologic visual core descriptions (Cochran, Stow, et al., 1989) most samples are from clay (T1), which constitutes the major lithology, and from silty clay (T2) and nannofossil ooze (CB1).

All samples were dried and washed through a $63-\mu \mathrm{m}$ sieve. The residues were mostly very scarce and in some cases there was no residue at all. Larger quantities were obtained from core-catchers.

The biogenic and nonbiogenic components of all samples were investigated on the total residue $(>63 \mu \mathrm{m})$. Quantitative study on benthic foraminifers was carried out only on the fraction $>150 \mu \mathrm{m}$ to compare our data with those of Corliss (1979a). Benthic foraminifers were picked and counted in all samples, even though they were of very poor quality. Not all 

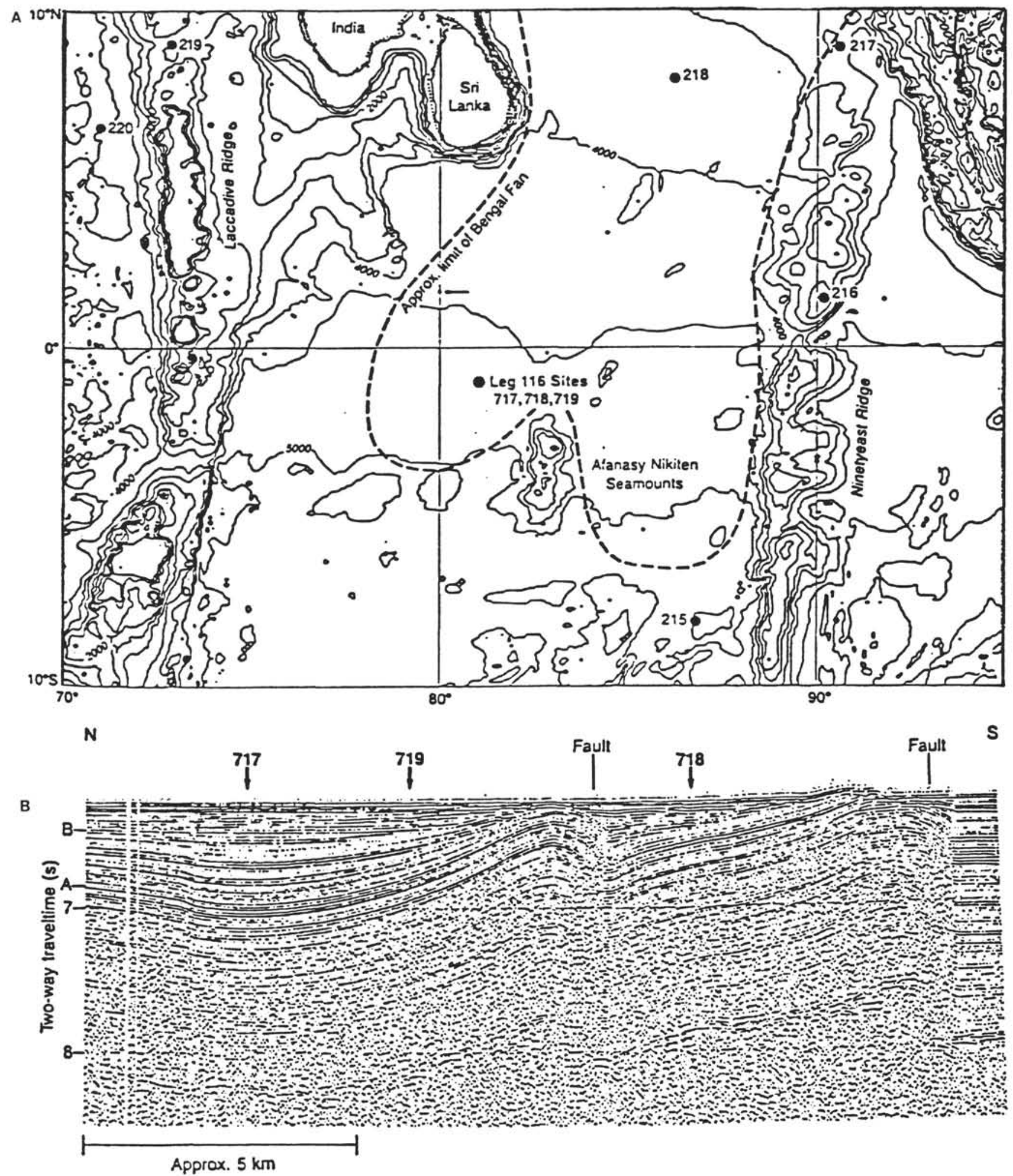

Figure 1. A. Location map of ODP Sites 717, 718, and 719; B. Seismic reflection profile across the Leg 116 sites. Faults bounding the tilted blocks and prominent unconformities $\mathrm{A}$ and $\mathrm{B}$ are indicated. 
Table 1. List of examined samples in Holes 717B and C, 718C, and 719A. The fossiliferous samples are marked with asterisks.

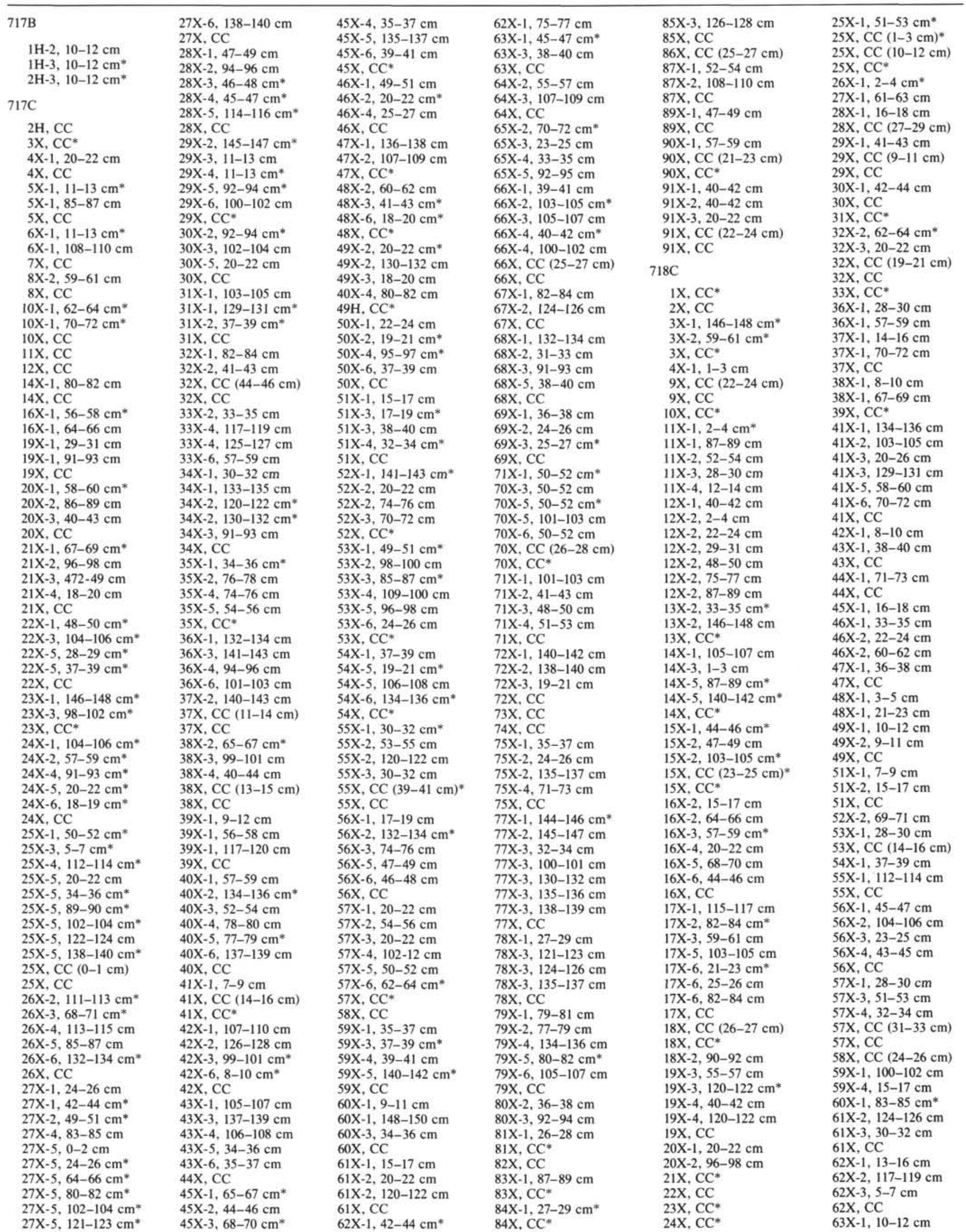


Table 1 (continued).

\begin{tabular}{|c|c|c|c|c|c|}
\hline $718 \mathrm{C}$ (continued) & $\begin{array}{l}74 \mathrm{X}-1,48-50 \mathrm{~cm} \\
75 \mathrm{X}, \mathrm{CC}\end{array}$ & $\begin{array}{l}94 \mathrm{X}-2,8-10 \mathrm{~cm} \\
94 \mathrm{X}-4,113-114 \mathrm{~cm}\end{array}$ & $\begin{array}{l}16 \mathrm{X}-3,106-108 \mathrm{~cm} \\
16 \mathrm{X}-4,16-18 \mathrm{~cm}^{*}\end{array}$ & $\begin{array}{l}22 \mathrm{X}-4,53-55 \mathrm{~cm} \\
22 \mathrm{X}-5,37-39 \mathrm{~cm}\end{array}$ & $\begin{array}{l}35 \mathrm{X}-4,38-40 \mathrm{~cm} \\
35 \mathrm{X}, \mathrm{CC}^{*}\end{array}$ \\
\hline $63 \mathrm{X}-2,37-39 \mathrm{~cm}$ & $76 \mathrm{X}-1,30-32 \mathrm{~cm}$ & $94 X-5,64-66 \mathrm{~cm}$ & $16 \mathrm{X}-4,120-128 \mathrm{~cm}^{*}$ & $22 \times-6,77-79 \mathrm{~cm}^{*}$ & $36 X-2,40-42 \mathrm{~cm}$ \\
\hline $63 X-5,67-69 \mathrm{~cm}$ & $76 \mathrm{X}, \mathrm{CC}$ & $94 \mathrm{X}-6,117-119 \mathrm{~cm}$ & $16 X-5,68-70 \mathrm{~cm}^{*}$ & $22 \mathrm{X}, \mathrm{CC}$ & $36 \mathrm{X}-4,120-122 \mathrm{~cm}$ \\
\hline $63 \mathrm{X}-6,53-55 \mathrm{~cm}$ & $78 \mathrm{X}-4,72-74 \mathrm{~cm}$ & $94 \mathrm{X}, \mathrm{CC}^{*}$ & $16 \mathrm{X}-6,97-99 \mathrm{~cm}$ & $23 \mathrm{X}-2,84-86 \mathrm{~cm}$ & $36 \mathrm{X}-5,111-113 \mathrm{~cm}$ \\
\hline $63 \mathrm{X}, \mathrm{CC}$ & $78 \mathrm{X}-5,30-32 \mathrm{~cm}$ & $95 \mathrm{X}, \mathrm{CC}$ & $16 \mathrm{X}, \mathrm{CC}$ & $23 \mathrm{X}, \mathrm{CC}$ & $36 X-6,67-69 \mathrm{~cm}^{*}$ \\
\hline $65 X-1,70-72 \mathrm{~cm}$ & $78 \mathrm{X}, \mathrm{CC}^{*}$ & $96 \mathrm{X}, \mathrm{CC}$ & $17 \mathrm{X}-1,34-36 \mathrm{~cm}$ & $25 \mathrm{X}-1,49-51 \mathrm{~cm}$ & $36 \mathrm{X}, \mathrm{CC}$ \\
\hline $65 \mathrm{X}-2,86-88 \mathrm{~cm}$ & $79 X-1,136-138 \mathrm{~cm}$ & $97 X, C C$ & $17 X-2,142-144 \mathrm{~cm}$ & $26 \mathrm{X}, \mathrm{CC}^{*}$ & $37 \mathrm{X}-1,76-78 \mathrm{~cm}$ \\
\hline $65 \mathrm{X}, \mathrm{CC}$ & $79 X-2,57-59 \mathrm{~cm}^{*}$ & $98 \mathrm{X}, \mathrm{CC}(1-3 \mathrm{~cm})$ & $17 \mathrm{X}-3,122-124 \mathrm{~cm}^{*}$ & $27 \mathrm{X}-1,45-47 \mathrm{~cm}$ & $37 X-2,90-92 \mathrm{~cm}$ \\
\hline $66 \mathrm{X}-1,34-36 \mathrm{~cm}$ & $80 X-1,60-62 \mathrm{~cm}$ & & $17 \mathrm{X}-5,87-89 \mathrm{~cm} *$ & $27 \mathrm{X}-2,108-110 \mathrm{~cm}$ & $37 \mathrm{X}-3,40-42 \mathrm{~cm}$ \\
\hline $66 \mathrm{X}-2,71-73 \mathrm{~cm}$ & $80 X-2,60-62 \mathrm{~cm}$ & $719 \mathrm{~A}$ & $17 \mathrm{X}-6,136-138 \mathrm{~cm}^{*}$ & $28 X-3,70-72 \mathrm{~cm}$ & $37 \mathrm{X}-3,132-135 \mathrm{~cm}$ \\
\hline $66 \mathrm{X}-3,36-38 \mathrm{~cm}$ & $80 X-3,11-13 \mathrm{~cm}$ & $1 \mathrm{H}-1,120-122 \mathrm{~cm}^{*}$ & $17 X-7,30-32 \mathrm{~cm}^{*}$ & $28 \mathrm{X}-4,69-71 \mathrm{~cm}$ & $37 \mathrm{X}-4,87-89 \mathrm{~cm}$ \\
\hline $66 \mathrm{X}, \mathrm{CC}$ & $80 \mathrm{X}, \mathrm{CC}$ & $1 \mathrm{H}-2,69-71 \mathrm{~cm}^{*}$ & $17 \mathrm{X}, \mathrm{CC}$ & $28 \mathrm{X}-6,121-123 \mathrm{~cm}^{*}$ & $37 \mathrm{X}-5,87-89 \mathrm{~cm}^{*}$ \\
\hline $67 X-1,46-48 \mathrm{~cm}$ & $81 \mathrm{X}, \mathrm{CC}$ & $1 \mathrm{H}-3,94-96 \mathrm{~cm}^{*}$ & $18 X-1,105-107 \mathrm{~cm}$ & $28 \mathrm{X}-6,127-128 \mathrm{~cm}^{*}$ & $37 \mathrm{X}, \mathrm{CC}^{*}$ \\
\hline $67 \mathrm{X}-2,122-124 \mathrm{~cm}$ & $82 X-1,125-127 \mathrm{~cm}$ & IH, CC & $18 \mathrm{X}-2,90-92 \mathrm{~cm}$ & $28 \mathrm{X}-6,133-135 \mathrm{~cm}^{*}$ & $38 \mathrm{X}-1,97-99 \mathrm{~cm}$ \\
\hline $67 X-3,52-54 \mathrm{~cm}$ & $82 \mathrm{X}, \mathrm{CC}$ & $2 X-1,17-18 \mathrm{~cm}^{*}$ & $18 \mathrm{X}-3,99-101 \mathrm{~cm}$ & $28 \mathrm{X}, \mathrm{CC}$ & $38 \mathrm{X}-2,66-68 \mathrm{~cm}^{*}$ \\
\hline $67 \mathrm{X}, \mathrm{CC}^{*}$ & $83 \mathrm{X}-1,80-82 \mathrm{~cm}$ & $2 X-1,59-61 \mathrm{~cm}$ & $18 \mathrm{X}-4,53-55 \mathrm{~cm}$ & $29 X-2,51-53 \mathrm{~cm}$ & $38 \mathrm{X}-3,30-32 \mathrm{~cm}$ \\
\hline $68 \mathrm{X}-1,22-24 \mathrm{~cm}$ & $83 \mathrm{X}, \mathrm{CC}$ & $2 \mathrm{X}, \mathrm{CC}$ & $18 X-5,101-103 \mathrm{~cm}^{*}$ & $29 \mathrm{X}-2,99-102 \mathrm{~cm}^{*}$ & $38 X-4,60-62 \mathrm{~cm}$ \\
\hline $68 \mathrm{X}-2,36-38 \mathrm{~cm}$ & $84 X-1,14-16 \mathrm{~cm}$ & $3 \mathrm{X}, \mathrm{CC}^{*}$ & $18 X-6,85-87 \mathrm{~cm}$ & $29 \mathrm{X}, \mathrm{CC}^{*}$ & $38 \mathrm{X}-5,78-80 \mathrm{~cm}^{*}$ \\
\hline $69 X-1,15-17 \mathrm{~cm}$ & $85 \mathrm{X}-1,8-10 \mathrm{~cm}$ & $4 \mathrm{X}, \mathrm{CC}$ & $18 \mathrm{X}, \mathrm{CC}$ & $30 X-2,141-143 \mathrm{~cm}$ & $38 \mathrm{X}, \mathrm{CC}^{*}$ \\
\hline $69 \mathrm{X}, \mathrm{CC}$ & $85 \mathrm{X}, \mathrm{CC}$ & $5 \mathrm{X}-1,29-31 \mathrm{~cm}^{*}$ & $19 X-1,112-114 \mathrm{~cm}^{*}$ & $30 \mathrm{X}-4,80-82 \mathrm{~cm}^{*}$ & $39 X-1,117-119 \mathrm{~cm}$ \\
\hline $70 X-1,117-119 \mathrm{~cm}$ & $86 \mathrm{X}-3,26-27 \mathrm{~cm}$ & $6 \mathrm{X}-1,7-9 \mathrm{~cm}$ & $19 X-2,52-54 \mathrm{~cm}^{*}$ & $30 \mathrm{X}, \mathrm{CC}$ & $39 \mathrm{X}, \mathrm{CC}(25-27 \mathrm{~cm})$ \\
\hline $71 \times-1,40-42 \mathrm{~cm}$ & $87 \mathrm{X}-2,20-22 \mathrm{~cm}$ & $7 X-1,15-17 \mathrm{~cm}$ & $19 X-3,76-78 \mathrm{~cm}$ & $31 \mathrm{X}-1,140-142 \mathrm{~cm}^{*}$ & $40 \times-1,7-9 \mathrm{~cm}$ \\
\hline $71 X-2,78-80 \mathrm{~cm}$ & $88 \mathrm{X}-1,16-18 \mathrm{~cm}$ & $8 X-1,6-8 \mathrm{~cm}$ & $19 \mathrm{X}, \mathrm{CC}(13-15 \mathrm{~cm})^{*}$ & $31 X-3,113-115 \mathrm{~cm}$ & $41 X, C^{*}$ \\
\hline $71 X-5,77-79 \mathrm{~cm}$ & $88 \mathrm{X}-3,10-12 \mathrm{~cm}$ & $9 \mathrm{X}, \mathrm{CC}^{*}$ & $19 \mathrm{X}, \mathrm{CC}$ & $31 \mathrm{X}-3,123-125 \mathrm{~cm}^{*}$ & $42 \mathrm{X}-1,39-40 \mathrm{~cm}$ \\
\hline $71 \mathrm{X}, \mathrm{CC}$ & $88 \mathrm{X}-3,91-93 \mathrm{~cm}$ & $10 \mathrm{X}, \mathrm{CC}$ & $20 \mathrm{X}, \mathrm{CC}^{*}$ & $31 \mathrm{X}, \mathrm{CC}$ & $43 \mathrm{X}-1,15-17 \mathrm{~cm}^{*}$ \\
\hline $72 X-3,110-112 \mathrm{~cm}$ & $88 X-4,12-14 \mathrm{~cm}$ & $11 \mathrm{X}, \mathrm{CC}$ & $21 \mathrm{X}-1,120-122 \mathrm{~cm}$ & $32 X-3,66-68 \mathrm{~cm}^{*}$ & $43 \mathrm{X}, \mathrm{CC}$ \\
\hline $72 X-4,135-137 \mathrm{~cm}^{*}$ & $90 \mathrm{X}-1,100-102 \mathrm{~cm}$ & $13 \mathrm{X}-1,23-25 \mathrm{~cm}$ & $21 \mathrm{X}-2,55-57 \mathrm{~cm}$ & $34 \mathrm{X}-3,41-43 \mathrm{~cm}^{*}$ & $44 X-1,33-35 \mathrm{~cm}$ \\
\hline $72 X-5,142-144 \mathrm{~cm}^{*}$ & $90 \mathrm{X}, \mathrm{CC}(9-11 \mathrm{~cm})$ & $14 X-2,52-54 \mathrm{~cm}$ & $21 X-3,20-22 \mathrm{~cm}$ & $34 X-4,3-5 \mathrm{~cm}^{*}$ & $45 \mathrm{X}, \mathrm{CC}$ \\
\hline $72 X-6,4-6 \mathrm{~cm}^{*}$ & $90 \mathrm{X}, \mathrm{CC}$ & $14 X-2,86-88 \mathrm{~cm}$ & $21 \mathrm{X}, \mathrm{CC}(9-11 \mathrm{~cm})$ & $34 X-7,24-26 \mathrm{~cm}^{*}$ & $47 \mathrm{X}, \mathrm{CC}$ \\
\hline $72 \mathrm{X}, \mathrm{CC}$ & $91 X-1,20-22 \mathrm{~cm}$ & $14 \mathrm{X}, \mathrm{CC}^{*}$ & $21 \mathrm{X}, \mathrm{CC}^{*}$ & $34 \mathrm{X}, \mathrm{CC}^{*}$ & $48 X-1,83-85 \mathrm{~cm}$ \\
\hline $73 \mathrm{X}-3,46-48 \mathrm{~cm}$ & $91 \mathrm{X}, \mathrm{CC}(15-17 \mathrm{~cm})$ & $16 \mathrm{X}-1,72-74 \mathrm{~cm}$ & $22 \mathrm{X}-1,8-10 \mathrm{~cm}$ & $35 X-1,62-68 \mathrm{~cm}$ & $48 X-6,63-65 \mathrm{~cm}$ \\
\hline $73 \mathrm{X}, \mathrm{CC}$ & $91 X, C C$ & $16 X-1,145-147 \mathrm{~cm}$ & $22 X-2,85-87 \mathrm{~cm}$ & $35 X-2,93-97 \mathrm{~cm}$ & $48 \mathrm{X}, \mathrm{CC}^{*}$ \\
\hline $74 \mathrm{X}-1,13-15 \mathrm{~cm}$ & $92 \mathrm{X}, \mathrm{CC}$ & $16 \mathrm{X}-3,50-52 \mathrm{~cm}$ & $22 \mathrm{X}-3,53-55 \mathrm{~cm}^{*}$ & $35 \mathrm{X}-3,63-65 \mathrm{~cm}^{*}$ & $\begin{array}{l}49 X-1,2-4 \mathrm{~cm} \\
49 X-3,130-132 \mathrm{~cm}\end{array}$ \\
\hline
\end{tabular}

recognized species are listed in the range charts because of their very sporadic and scattered occurrence (Tables 2-4). In most cases, species were grouped at the generic level, and barren samples were omitted. The different kinds of groupings used in the range charts are listed in the Appendix.

\section{COMMENTS ON THE BENTHIC ASSEMBLAGES}

Of a total number of 684 examined samples from the three sites (Table 1), only 187 were fossiliferous ( 102 at Site 717,38 at Site 718, 47 at Site 719), ranging in age from middle Miocene to Holocene. Most of them yielded less than 50 specimens; the early Miocene sequence occurring at Site 718 (Gartner, this volume) did not contain benthic foraminifers.

Micropaleontologic analysis did not reveal significant changes in the benthic foraminifer assemblages through the three sequences. The important change in the benthic fauna recorded around the middle Miocene (Woodruff and Douglas, 1981; Thomas, 1985) is older than the present record and cannot be documented in these sections.

Because of the turbiditic origin of the sediments, most of the benthic foraminifers are displaced from their habitat. Thus, most samples contain a fauna of mixed bathymetry. Based on the living depth range (e.g., Murray, 1973; Phleger, 1960; Boltovskoy and Wright, 1976), three groups of benthic foraminifers were tentatively distinguished and named Assemblages 1,2 , and 3 .

Assemblage 1 consists of taxa associated with cold abyssal water masses (Corliss, 1979a); Assemblage 2 includes taxa not strictly limited to a narrow bathymetric range but distributed from shelf to lower bathyal environment, and Assemblage 3 includes only taxa indicating very shallow water.

Assemblage 1. This group is represented by Nuttallides umbonifera (at times dominant), Epistominella exigua, Pullenia bulloides, Oridorsalis umbonatus, Planulina wuellerstorfi, and Globocassidulina subglobosa. In the southeastern Indian Ocean, Corliss (1979a) distinguished two Holocene deep-sea benthic foraminifer assemblages. The first, dominated by Nuttallides umbonifera, Planulina wuellerstorfi, Globocassidulina subglobosa, and Pullenia bulloides, is inferred to be associated with Antarctic Bottom Water (AABW). The second assemblage, dominated by Epistominella exigua and Uvigerina spp., is associated with Indian Bottom Water (IBW). In Leg 116 samples, Epistominella exigua and Uvigerina spp. were not encountered as dominant assemblage. In the eastern equatorial Indian Ocean, Peterson (1984) identified within IBW below $3800 \mathrm{~m}$ a biofacies very similar to Assemblage 1. The major contributors of such a biofacies are Nuttallides umbonifera and Epistominella exigua, but Globocassidulina subglobosa, Planulina wuellerstorfi, Oridorsalis umbonatus, and Pullenia bulloides are common as well. Peterson (1984) noticed that $N$. umbonifera is more abundant below $4000 \mathrm{~m}$, and Epistominella exigua above $4000 \mathrm{~m}$. Therefore, IBW below $3800 \mathrm{~m}$ and $\mathrm{AABW}$ do appear to affect the foraminiferal pattern in the equatorial Indian Ocean.

The species of Assemblage 1 are the most common and recurrent throughout all sites, but they only peak at some thin horizons at the top of the biogenic turbidite sequences in Cores 116-717C-21X, -22X, -24X, -25X (CN1a to CN13a), 116-717C28X (CN12c), and in Cores 116-719A-16X and -17X (CN13a to CN12d). It is not clear if Assemblage 1 is autochthonous or resedimented. It generally co-occurs with forms of Assemblage 2, and rarely, with very scarce specimens of Assemblage 3 .

In Site 717, the lowest peak of Assemblage 1 (Sample 116-717C-28X-4, 45-47 cm) occurs within the CN12c nannofossil zone above the last occurrence (LO) of Discoaster surculus and D. asymmetricus (2.42 Ma, lower part of the Matuyama Chron; Baldauf et al., 1987; Gartner et al., 1983). No similar peaks were detected in this chronological position at Sites 718 and 719. At Site 718 this absence may result from the presence of an unconformity across that interval (Gartner, this volume); at Site 719 the analyzed samples of this part of the sequence are barren and/or show strong dissolution. This late Pliocene Assemblage 1 peak at Site 717 may be related to 
the climatic deterioration that started near the Gauss/ Matuyama boundary (Shackleton et al., 1984; Shackleton and Cita, 1979; Thunnell and Williams, 1983).

Two other peaks (Samples 116-717C-25X-1, 50-52 cm; 116-717C-24X-5, 20-22 cm; 116-717C-21X-1, 67-69 cm; $116-717 \mathrm{C}-21 \mathrm{X}-1,48-50 \mathrm{~cm}$ ) occur in the Pleistocene, above the FO of Gephyrocapsa oceanica (1.59 Ma, Rio et al., in press), and above the end of the small Gephyrocapsa Acme (0.93 Ma; Gartner, this volume), respectively. The latter peaks correlate well with those observed at Site 719 (Samples 116-719A-16X-4, 16-18 cm, 116-719A-16X-4, 120-122 $\mathrm{cm}, 116-719 \mathrm{~A}-16 \mathrm{X}-5,68-70 \mathrm{~cm}$, and 116-719A-17X-5, 87-89 $\mathrm{cm}$ ), and may thus represent a genuine paleoenvironmental signal. The Pleistocene peaks may possibly be related to the further climatic deterioration that occurred at about $0.8 \mathrm{Ma}$ (Williams et al., 1988). The timing of these peaks, however, is not so well constrained as to allow correlation with standard oxygen isotope stages (Williams et al., 1988).

Assemblage 2 comprises taxa that live from shelf to lower bathyal depths (Murray, 1973, among others). None of the species of this assemblage reaches high population density; their occurrence in the sediments is due to turbiditic displacement. The most common genera included in this group are: Anomalinoides, Bolivina, Brizalina, Bulimina, Cassidulina, Nonionella, Cibicidoides, Dentalina, Eggerella, Eponides, Fursenkoina, Gyroidinoides, Heterolepa, Hoeglundina, Karreriella, Melonis, Stainforthia, Pyrgo, Nodosaria, Sphaeroidina, Oolina, Lagena, Fissurina, Lenticulina, Pullenia, Laticarinina, Plectofrondicularia, Pleurostomella, and Stilostomella.

Assemblage 3 is characterized by taxa typical of an inner shelf environment (Florilus, Hanzawaia, Scutuloris, Triloculina, Sigmoilopsis, Quinqueloculina, Protoelphidium, and Textularia) and in some cases of very shallow water (Ammonia, Elphidium, Pararotalia, Pseudorotalia, and Amphistegina). The species of this group occur very sporadically and are always very rare and damaged. They occur mainly in the coarser turbidites and are probably derived from neritic areas much farther north (Ganges Delta) (Stow, et al., 1989). In most cases they are associated with Assemblage 2.

All the species occurring throughout the turbiditic sequences, except those from Assemblage 3, are mostly the same as those recorded by other authors in sediments deposited in bathyal and abyssal waters in the Indian Ocean (Boltovskoy, 1977, 1980; Corliss, 1979a, b, 1983; Burke, 1981; Peterson, 1984), North Atlantic (Thomas, 1986; Phleger, Parker, and Peirson, 1953), South Atlantic (Boersma, 1984; Lohmann, 1978; Mead, 1985), South Pacific (Resig, 1981) and equatorial Pacific (Woodruff, 1985; Thomas, 1985). They belong to the "modern" post-middle Miocene faunas of Thomas (1985).

In addition to these three assemblages, there is a fourth benthic association occurring in the biogenic turbidites. The fauna is dominated by small-sized $(<150 \mu \mathrm{m}$, not included in the counting), well-preserved benthic and planktonic foraminifers, pyritized radiolarians, mollusc fragments, echinoid remains, and ostracods. Terrigenous detrital matter is very scarce. This benthic foraminifer assemblage is rich in Bulimina, Bolivina, and Brizalina, but Uvigerina, Trifarina, Reussella, Suggrunda, Bolivinita, and Hyalinea also occur, as do shallower water forms such as Hanzawaia, Ammonia, Elphidium, and Rosalina. Foraminifers larger than $150 \mu \mathrm{m}$ are very rare or absent.

Sections 116-717C-25X-5 and 116-717C-27X-5, where two complete turbiditic cycles occur, were examined in detail to document the pattern of benthic foraminifer content and distribution in the biogenic turbidites (Figs. 2 and 3). At the base of the sequence, the residue is abundant, entirely biogenic, and yields a very rich assemblage. Only a few specimens of Assemblage 1 occur. At the very top part of the sequence, residue is scarce and mainly composed of fragments of planktonic foraminifers, phos- phatic remains, pyrite concretions, plant debris, and some representatives of Assemblage 1. The benthic foraminifers dominating the biogenic turbidites are indicative of outer shelf and/or upper slope environments. The source area of this assemblage could be the continental shelf of Sri Lanka, the eastern coast of India, or possibly seamounts. The abundance of very small planktonic foraminifers suggests an open marine environment. The associated very shallow water benthic taxa (like Rosalina, Ammonia, and Elphidium) may be considered as originally belonging to the outer shelf assemblage, and their occurrence at depths greater than those usually inhabited may be connected with more favorable environmental conditions (higher temperature) of water masses at low latitudes. The excellent preservation and concentration of the faunal assemblage are incompatible with long transport.

Some remarks on the distribution of Hyalinea balthica and the absence of agglutinated forms may be made. Hyalinea balthica is well known and documented in the Mediterranean Basin, where it is considered a northern guest. Its arrival in the Mediterranean area is considered to be connected with the Pleistocene climatic deterioration (Trevisan and Di Napoli, 1938; Ruggieri and Selli, 1950). In the Indian Ocean, however, Hyalinea balthica has been present since the late Miocene (CN9) at Sites 717 and 719, within the biogenic turbidites, and was recorded by Bandy (1968) in the "Miocene strata of Philippine Islands." These findings, in addition to the occurrence of $H$. balthica in the upper Pliocene of the Caribbean (van Morkhoven et al., 1986), suggest that this species may be of southern provenance rather than northern.

The absence of agglutinated foraminifers is quite surprising. In fact, only Eggerella bradyi, which is a persistent form, and very rare specimens of Textularia spp. and Siphotextularia $\mathrm{sp}$. were observed. The primitive agglutinated foraminifers (Rhabdammina-type fauna) that generally characterize deep-sea and turbiditic sediments were completely absent. This was also recorded from late Miocene sediments in southeast Pacific Basin (Rögl, 1976).

\section{BENTHIC FORAMINIFER PATTERN AND LITHOSTRATIGRAPHY}

Different intervals were distinguished in each site and named a, b, c, d, e, f, based on the benthic foraminifer distribution pattern and other parameters (presence of planktonic foraminifers, phosphatic remains, radiolarians, plant debris, quartz, and mica), as follows:

Interval a: the benthic foraminifer abundance is closely related to lithology. The coarser turbiditic layers, rich in detrital material, are barren or yield a very poor assemblage, whereas the thin intercalations of calcareous clays yield a richer association. Both lithologies mainly contain Assemblage 2 with a few shallow water indicators (Assemblage 3 ). Planktonic foraminifers, strongly affected by dissolution, were sometimes abundant.

Interval b: benthic foraminifers are absent or represented by very few specimens per sample; this interval generally coincides with poor recovery.

Interval c: this interval, coinciding with upper part of biogenic turbidites, contains the most abundant and diversified assemblage. Two kinds of assemblage are recognizable; the first one consists of intensely size-sorted forms and mostly occurs in the size fraction $<150 \mu \mathrm{m}$. The most common species are Brizalina spissa, Bolivinita quadrilatera, Bulimina marginata, Hyalinea balthica, and Eponides tumidulus. Besides benthic foraminifers, abundant small planktonic foraminifers, radiolarians, biogenic fragments, ostracods, pelecypods, echinoid remains, and plant debris occur. The second assemblage (size fraction $>150 \mu \mathrm{m}$ ) is mainly characterized by deep water forms of Assemblage 1 and by a few specimens belonging to Assemblage 2. The major peaks 
Table 2. Occurrence of benthic foraminifers in Holes 717B and 717C.

Sample interval $(\mathrm{cm})$

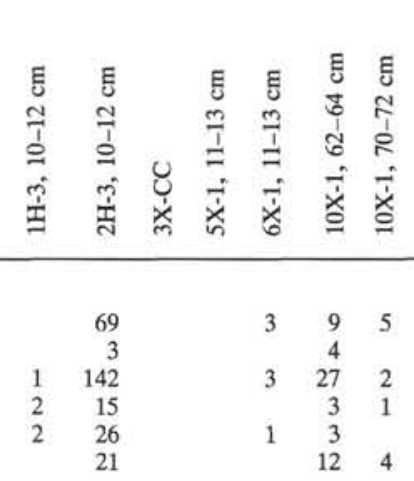

\section{ASSEMBLAGE 1}

Epistominella exigua

Globocassidulina subglobosa

Nuttallides umbonifera

Oridorsalis umbonatus

Planulina wuellerstorfi

Pullenia bulloides

ASSEMBLAGE 2

Anomalinoides spp.

bolivinids

Bolivinita quadrilatera

Bulimina marginata

buliminids

Buliminella spp.

Cassidulina spp.

Cibicidoides bradyi

Cibicidoides spp.

Dentalina spp-Nodosaria spp.

Eggerella bradyi

Ehrenbergina hystrix

Eponides tumidulus

Frondicularia sp.

Fursenkoina spp.

Gavelinopsis lobatulus

Gyroidinoides neosoldanit

Gyroidinoides altiformis

Gyroidinoides umbonatus gr.

Gyroidinoides laevigatus gr.

Gyroidinoides spp.

Heterolepa spp.

Hoeglundina elegans

Hyalinea balthica

Karreriella sp.

Lagena gr.

Laticarinina pauperata

Lenticulina spp.

Melonis nicobarensis

Melonis pompilioides

Plectofrondicularia spp.

Pleurostomella spp.

Pullenia spp.

Pyngo spp.

Reussella spinulosa

Sphaeroidina bulloides

Stainforthia spp.

uvigerinids

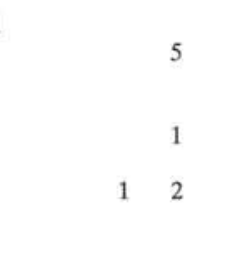

ASSEMBLAGE 3

Ammonia beccarii

Amphistegina sp.

Astrononion sp.

Cymbaloporetta sp.

Elphidium spp.

Florilus boueanus

Hanzawaia boueana

miliolids

Nonionella spp.

Pararotalia spp.

Rosalina globularis

Textularia gr.
11

2

111

16

11

15

3
6

6
16

6

15

2

21

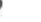

$\begin{array}{rr}1 & 22 \\ 25 & 4 \\ 172 & 186 \\ 15 & 36 \\ 31 & 20 \\ 50 & 26\end{array}$

$\begin{array}{rcc}4 & 2 & 2 \\ 1 & & \\ 39 & 14 & 1 \\ 2 & & 1 \\ 1 & 4 & 1 \\ 2 & 2 & \end{array}$

$\begin{array}{rrlrrr}41 & 2 & 4 & 10 & 47 & \\ 2 & 2 & & 6 & 27 & 1 \\ 93 & 38 & 2 & 117 & 389 & \\ 5 & 2 & & 85 & 77 & \\ 14 & & & 35 & 25 & \\ 2 & 1 & 1 & 22 & 49 & \end{array}$

3

18

$4 \quad 1$

21

1

$\begin{array}{rrrrr}5 & 2 & 1 & 1 & 15 \\ & 3 & 1 & 14 & 5 \\ & 1 & & 4 & \\ 8 & 3 & 1 & 20 & 39 \\ 2 & & & 1 & 3\end{array}$

$\begin{array}{rr}4 & 3 \\ 1 & 2 \\ 4 & 44\end{array}$




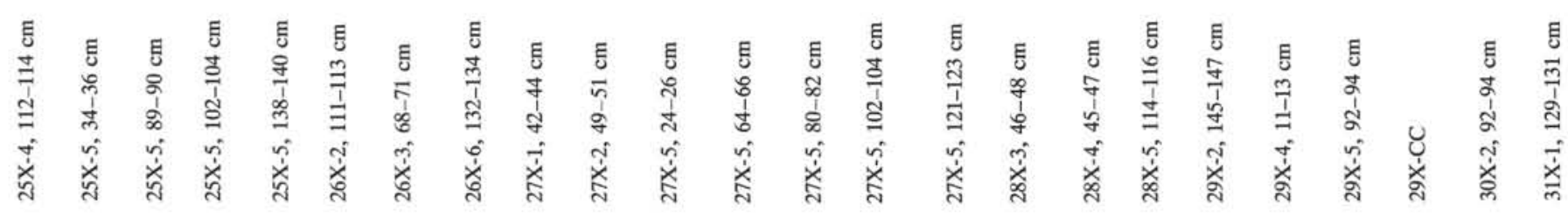

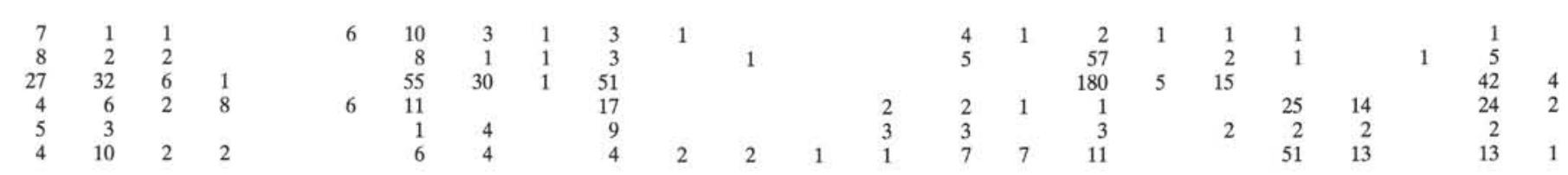
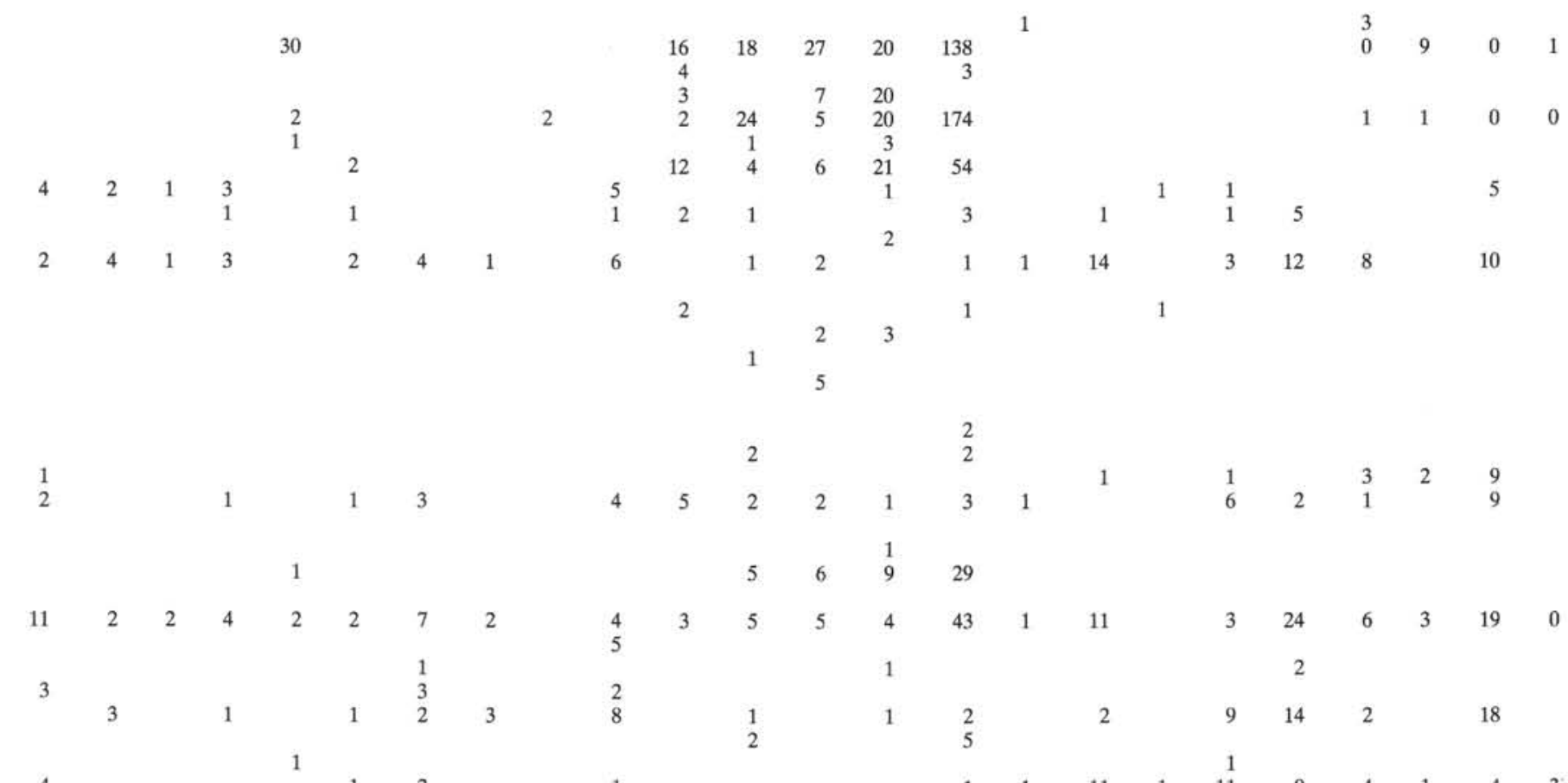

4

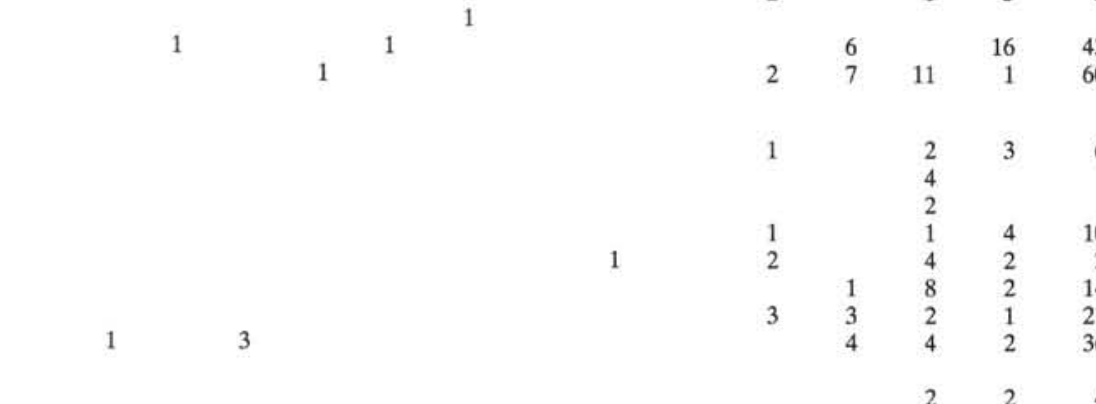

$\begin{array}{llllllll}1 & 1 & 1 & 1 & 1 & 2 & 1 & 1\end{array}$ 
Table 2 (continued).

Sample interval $(\mathrm{cm})$

ASSEMBLAGE 1

Epistominella exigua

Globocassidulina subglobosa

Nuttallides umbonifera

Oridorsalis umbonatus

Planulina wuellerstorfi

Pullenia bulloides

ASSEMBLAGE 2

Anomalinoides spp.

bolivinids

Bolivinita quadrilatera

Bulimina marginata

buliminids

Buliminella spp.

Cassidulina spp.

Cibicidoides bradyi

Cibicidoides spp.

Dentalina spp-Nodosaria spp.

Eggerella bradyi

Ehrenbergina hystrix

Eponides tumidulus

Frondicularia sp.

Fursenkoina spp.

Gavelinopsis lobatulus

Gyroidinoides neosoldanii

Gyroidinoides altiformis

Gyroidinoides umbonatus gr.

Gyroidinoides laevigatus gr.

Gyroidinoides spp.

Heterolepa spp.

Hoeglundina elegans

Hyalinea balthica

Karreriella sp.

Lagena gr.

Laticarinina pauperata

Lenticulina spp.

Melonis nicobarensis

Melonis pompilioides

Plectofrondicularia spp.

Pleurostomella spp.

Pullenia spp.

Pyngo spp.

Reussella spinulosa

Sphaeroidina bulloides

Stainforthia spp.

uvigerinids
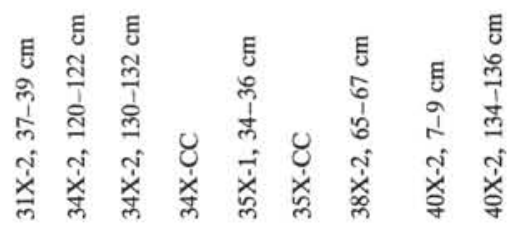

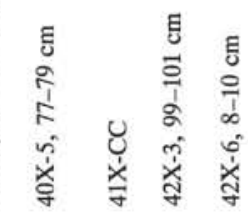

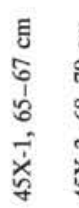

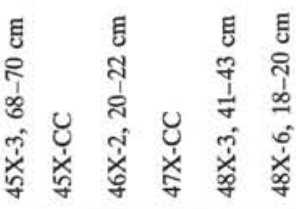

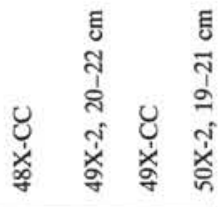

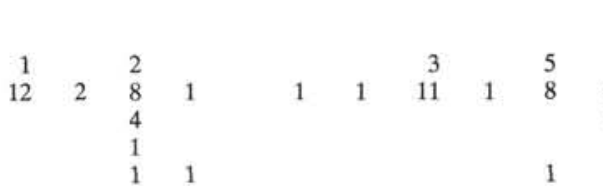

$$
\begin{array}{rrr}
3 & & \\
2 & 2 & 2 \\
35 & 8 & 6 \\
3 & & 3 \\
3 & & 3
\end{array}
$$

1

$\begin{array}{ll}3 & 3 \\ & 1 \\ 1 & 1\end{array}$

$\begin{array}{llll}4 & & 2 & 4 \\ 1 & 1 & & \end{array}$

2

11

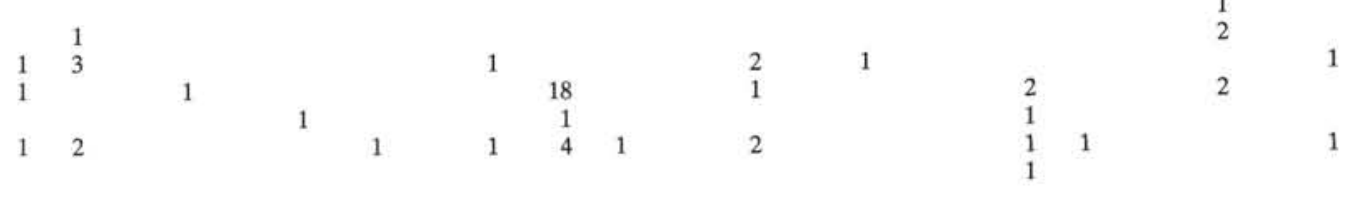

ASSEMBLAGE 3

Ammonia beccarii

Amphistegina sp.

Astrononion sp.

Cymbaloporetta sp.

Elphidium spp.

Florilus boueanus

Hanzawaia boueana

miliolids

Nonionella spp.

Pararotalia spp.

Rosalina globularis

Textularia gr.
129

1
1
3

4

3

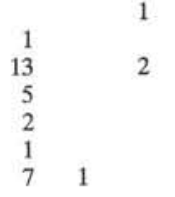

1

3

1
1

1
7 
Table 2 (continued).

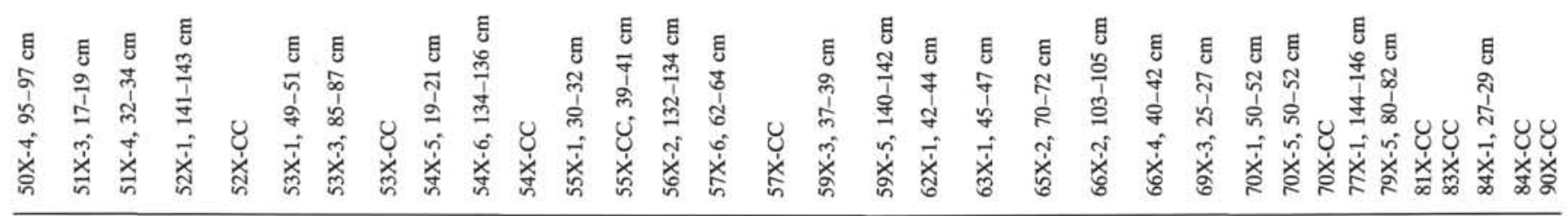

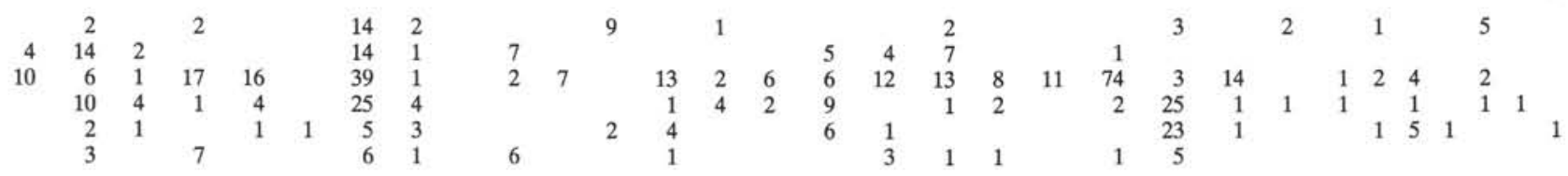

13

$\begin{array}{lllll}2 & 1 & 1 & & \\ & 1 & & 1 & 4\end{array}$
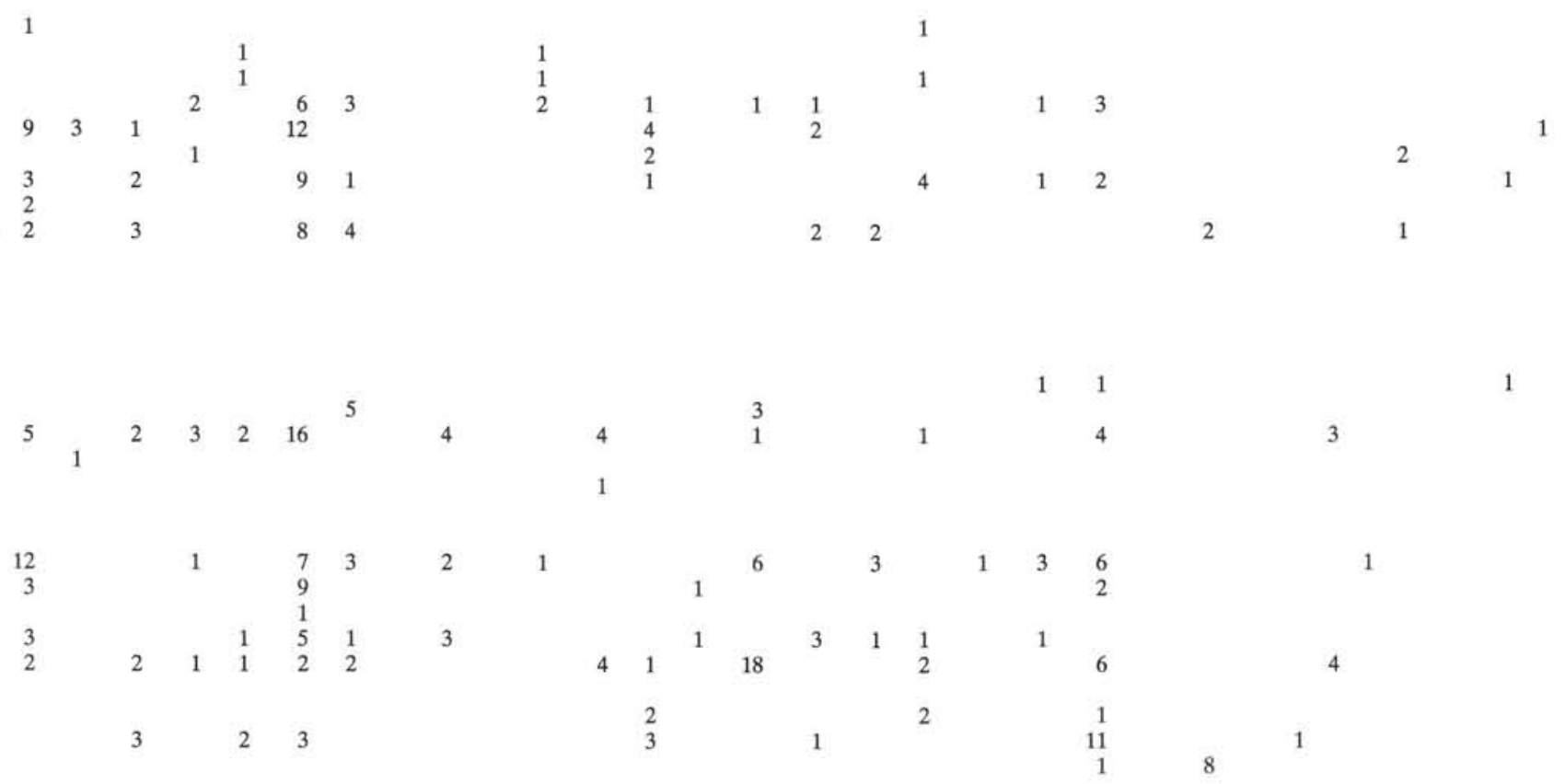

1

1

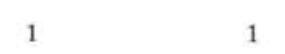

1 


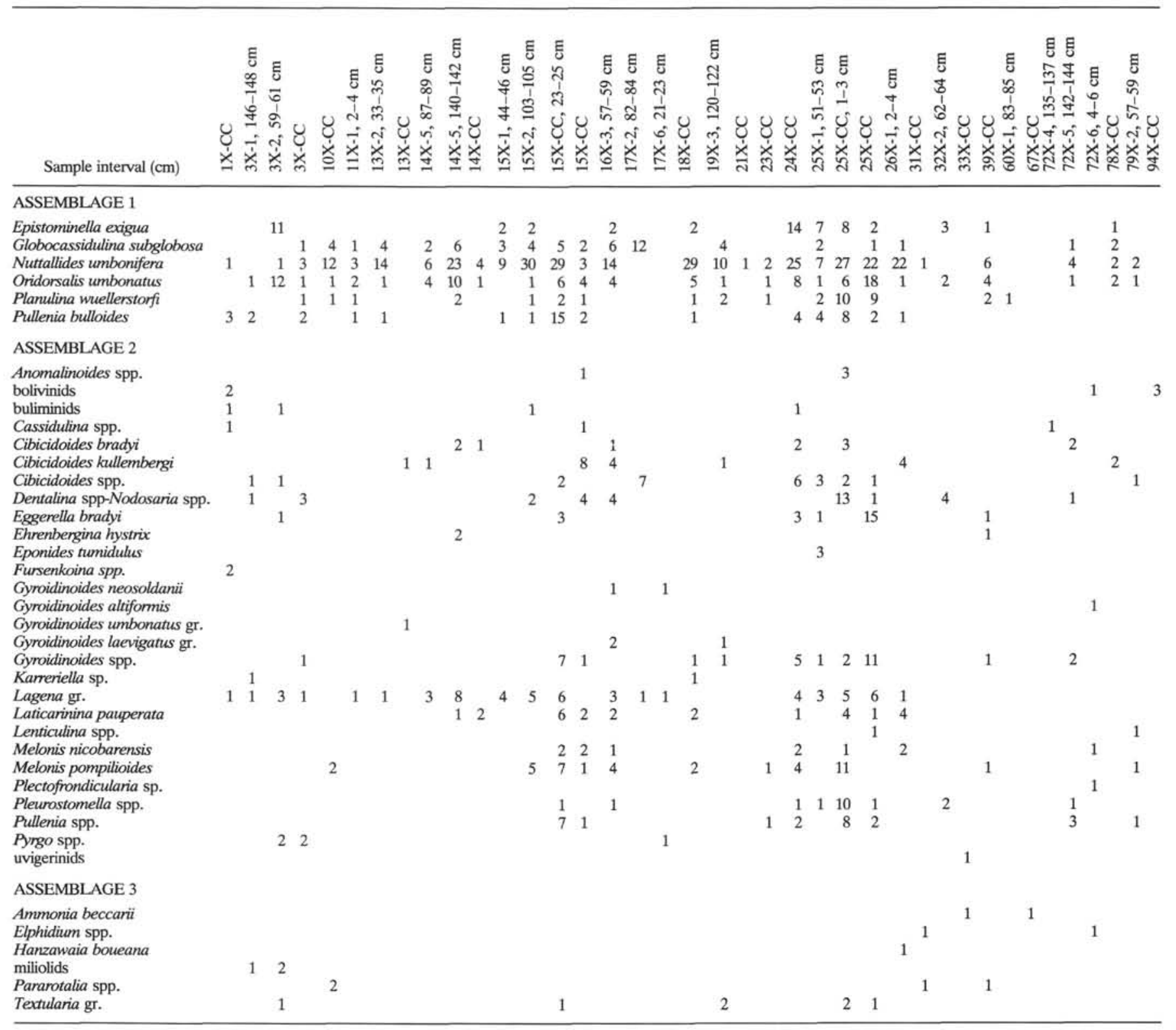

of Assemblage 1, however, occur within this interval above few biogenic turbidite cycles.

Interval d: samples from this interval are mostly bar-ren.

Interval e: recovery is good in this interval, and benthicforaminifers are well represented. Assemblages 1 and 2 occur in equal abundance. This interval differs from Interval $\mathrm{c}$ because the total number of Assemblage 1 species does not reach such high values. Phosphatic remains are common throughout the interval, whereas detrital material is always rare.

Interval $\mathrm{f}$ : all cores from this very thick interval are poorly fossiliferous and most samples are barren. Benthic foraminifers appear to be better represented in the upper part.

\section{SITE 717}

Benthic foraminifer assemblages show a distribution pattern as follows (Fig. 4):

\section{Interval a: Cores 116-717B-1H to $116-717 \mathrm{C}-10 \mathrm{X}$ (0-84 mbsf)}

This interval is represented in lithologic Unit II, and Assemblage 1 is abundant in Sample 116-717B-2H-3, 10-12 $\mathrm{cm}$, and in Sample 116-717C-10X-1, 62-64 cm. Phosphatic remains do not occur in this interval, and fragments of planktonic foraminifers are abundant only in Samples 116717C-10X-1, 62-64 cm, and 116-717C-10X-1, 70-72 cm.

\section{Interval b: Cores 116-717C-11X to $-20 X$ (84-169.5 mbsf)}

This interval is also recognizable in lithologic Unit II. Benthic foraminifers are absent or represented by less than three specimens per sample. 
Sample interval $(\mathrm{cm})$

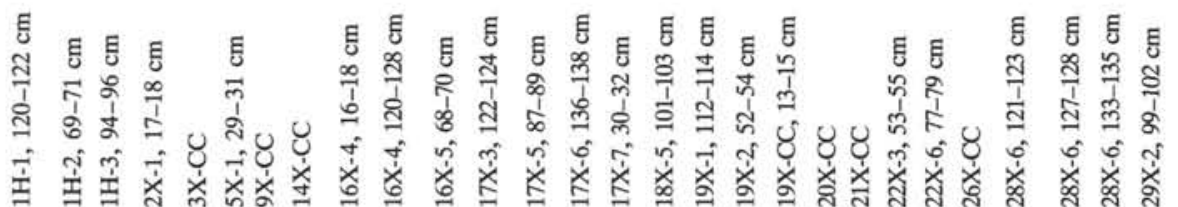

ASSEMBLAGE 1

Epistominella exigua

Nuttallides umbonifera

Oridorsalis umbonatus

Plamulina wuellerstor

Pullenia bulloides

ASSEMBLAGE 2

Anomalinoides spp.

bolivinids

Bolivinita quadrilatera

buliminids

Buliminella spp.

Cassidulina spp.

Cibicidoides kullembergi

Cibicidoides spp.

Cibicidoides spp.

Dentalina spp-Nod
Eggerella bradyi

Eggerella bradyi
Eponides tumidulus

Eponides tumidulus
Fursenkina spp.

Gyroidinoides neosoldanit

Gyroidinoides altiformis

Gyroidinoides umbonatus gr.

Gyroidinoides laevigatus $\mathrm{gr}$.

Gyroidinodes laenarius

Gyroidinoides spp.

Heterolepa spp.

Heterolepa spp.
Hoeglundina elegans

Hyalinea balthica

Karreriella sp.

Lagena gr.

Laticarinina pauperata

Lenticulina spp.

Melonis nicobarensis

Pleurostomella

Pleurostomella
Pullenia spp.

Pyrgo spp.

Reussella spinulosa

Reussella spinulosa

Stainforthia spp.

Stainforthia
uvigerinids

ASSEMBLAGE 3

Ammonia beccarii

Florilus boueanus

Hanzawaia boueana

miliolids

Nonionella spp.

Rosalina globularis
Textularia gr.

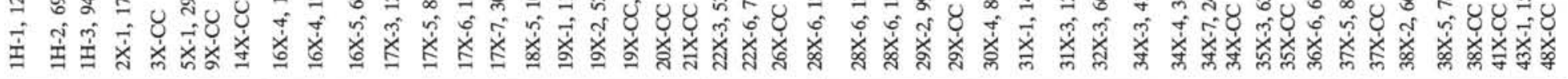

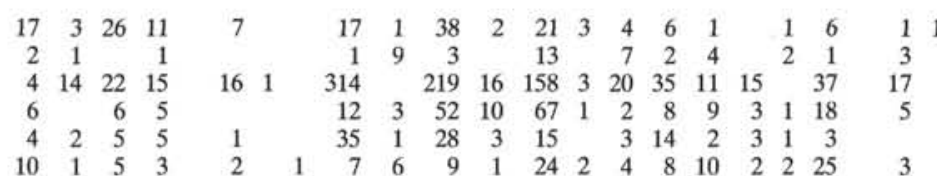

$\begin{array}{rrrr}1 & 2 & 2 & \\ & 3 & & 4 \\ 11 & 77 & 13 & 22 \\ 12 & 11 & 1 & 9 \\ 5 & 6 & & 4 \\ & 10 & 1 & 4\end{array}$

$\begin{array}{rr}4 & \\ 22 & \\ 9 & \\ 4 & 1 \\ 4 & \end{array}$

$\begin{array}{rrrr}13 & & 2 & \\ 2 & 10 & 5 \\ 2 & 28 & & 21\end{array}$

$\begin{array}{llllllll}1 & 1 & 2 & 1 & 2 & 2 & 1 & 1\end{array}$

1015

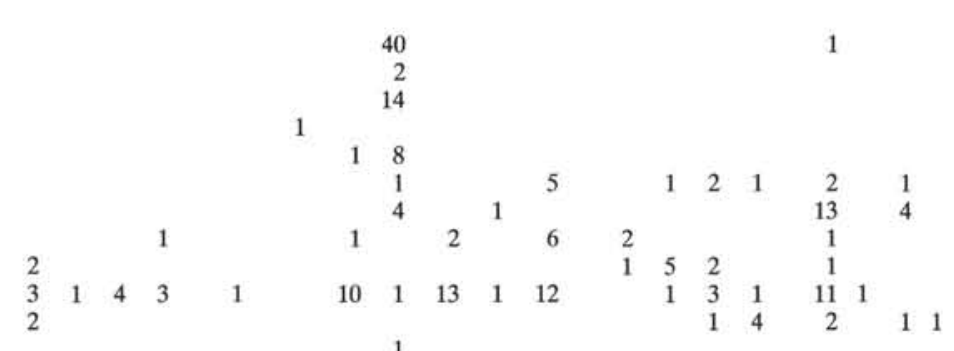

2

1

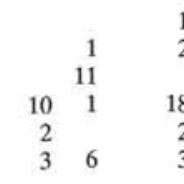

1
1
1

$\begin{array}{lll}7 & 3 & 1\end{array}$

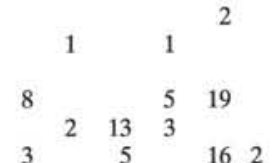

22

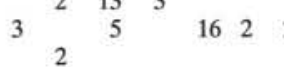

6

16

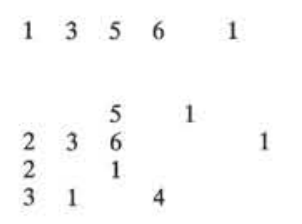

$23 \quad 13$

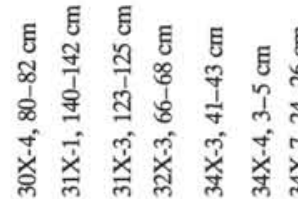

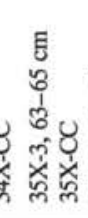

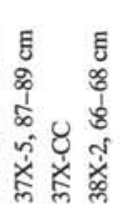

ह

8 


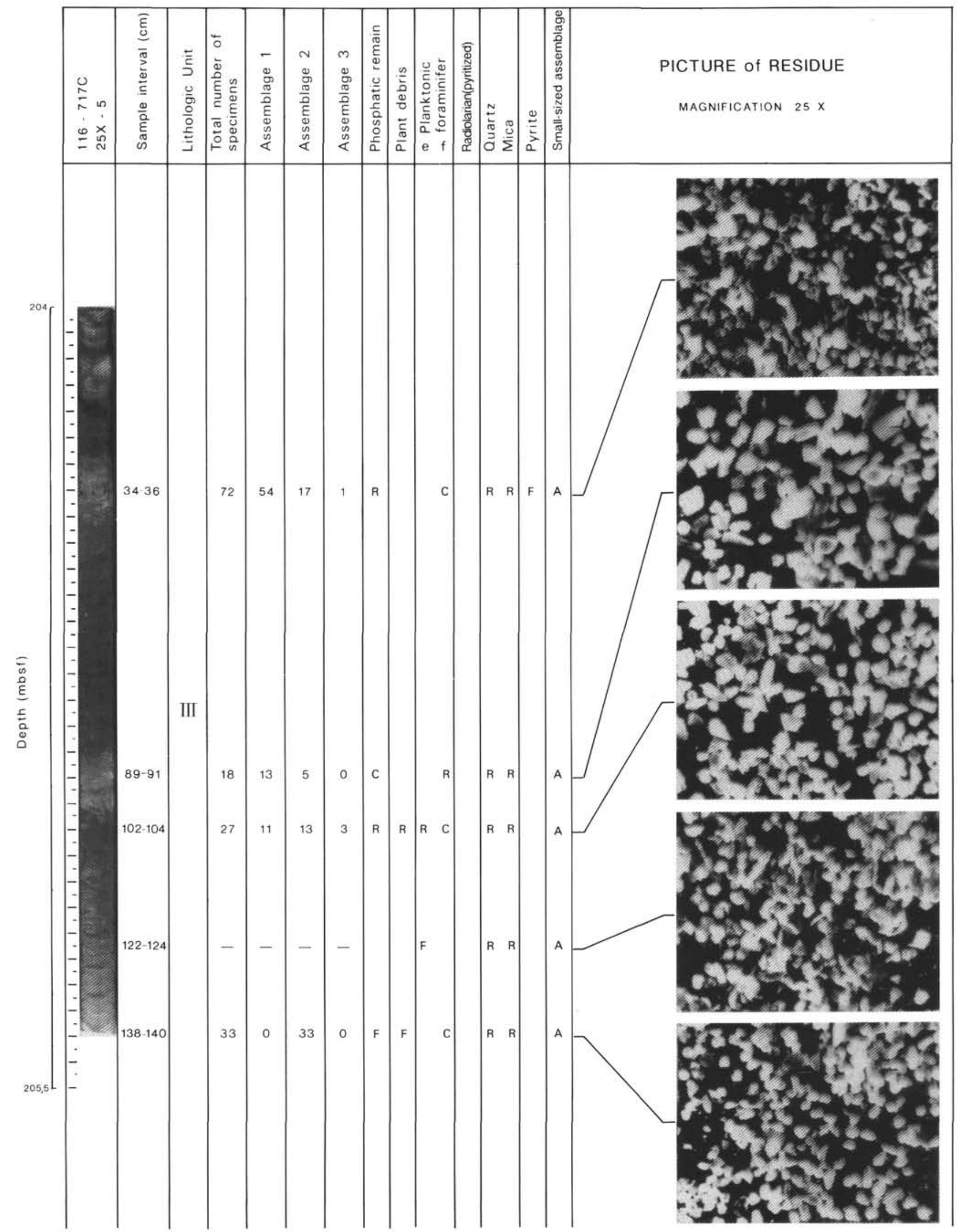

Figure 2. Faunal composition within the biogenic turbidites of Section 116-717C-25X-5. 


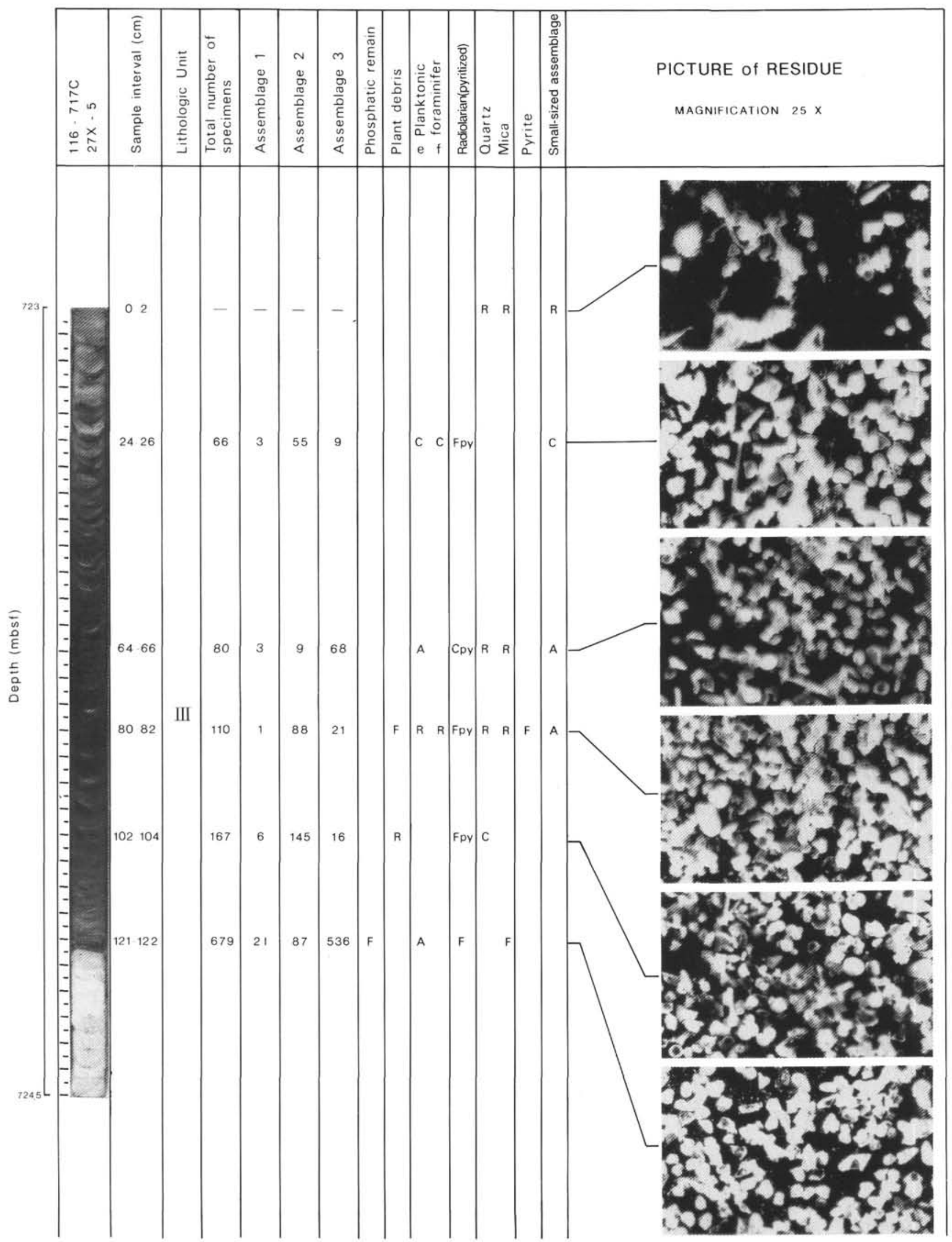

Figure 3. Faunal composition within the biogenic turbidites of Section 116-717C-27X-5. 


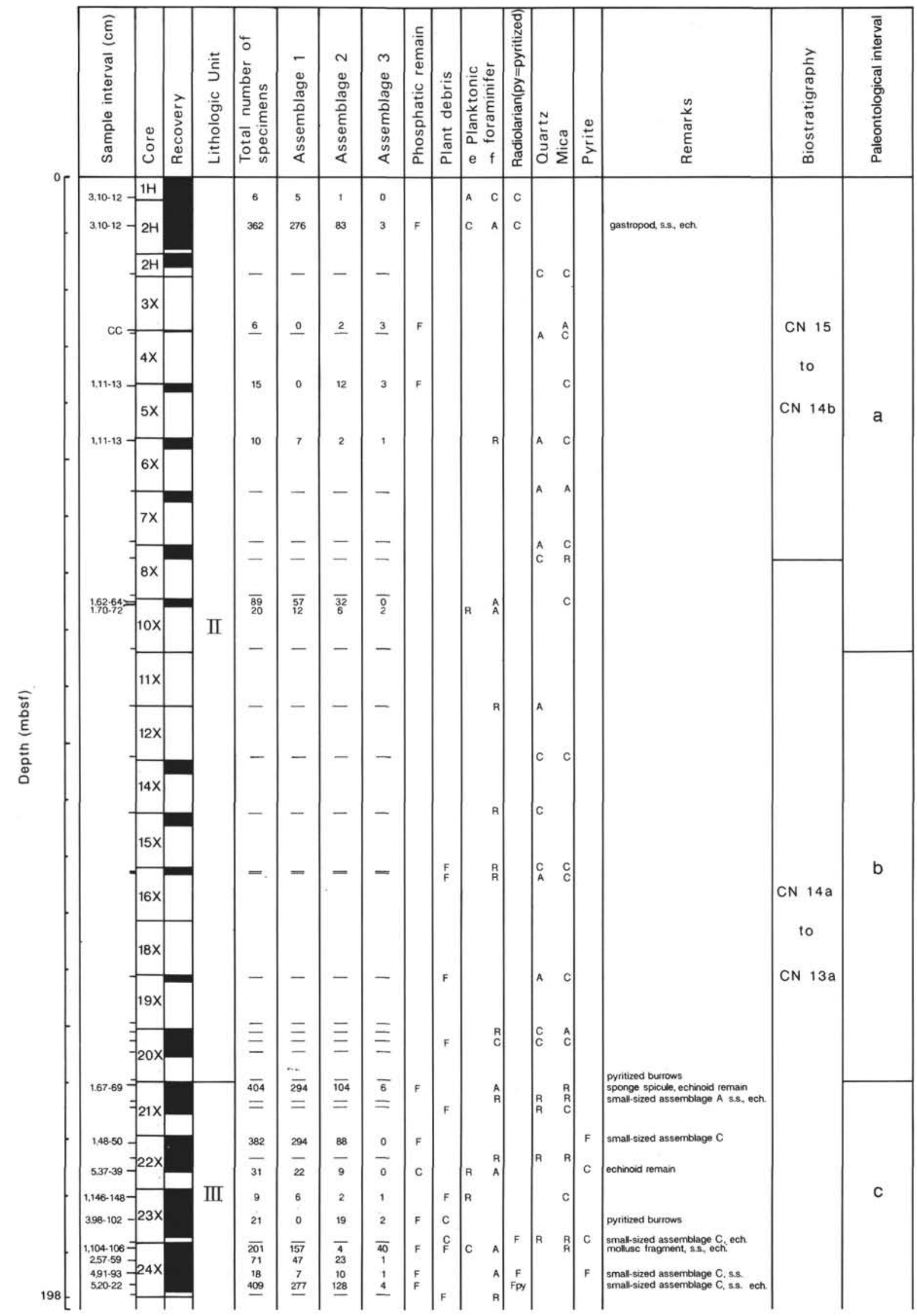

Figure 4. Synthesis of the biogenic and nonbiogenic components of Site 717. Lowest cores belonging to Unit V are not plotted. Legend: A-abundant; $\mathrm{C}-$ common; $\mathrm{F}$-few; $\mathrm{R}$-rare; ech.—echnoid remains; s.s.—sponge spicule. 


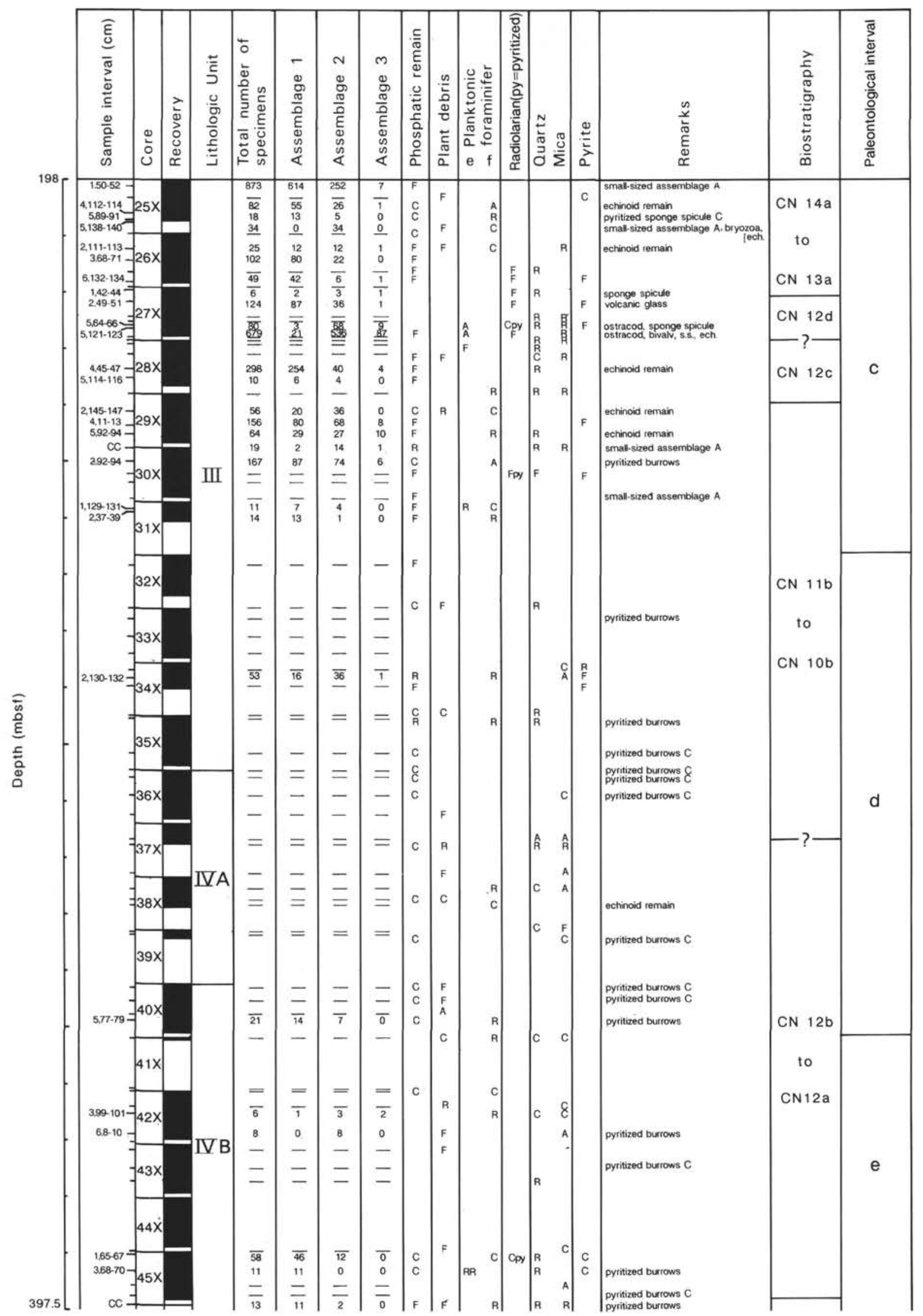

Figure 4 (continued). 


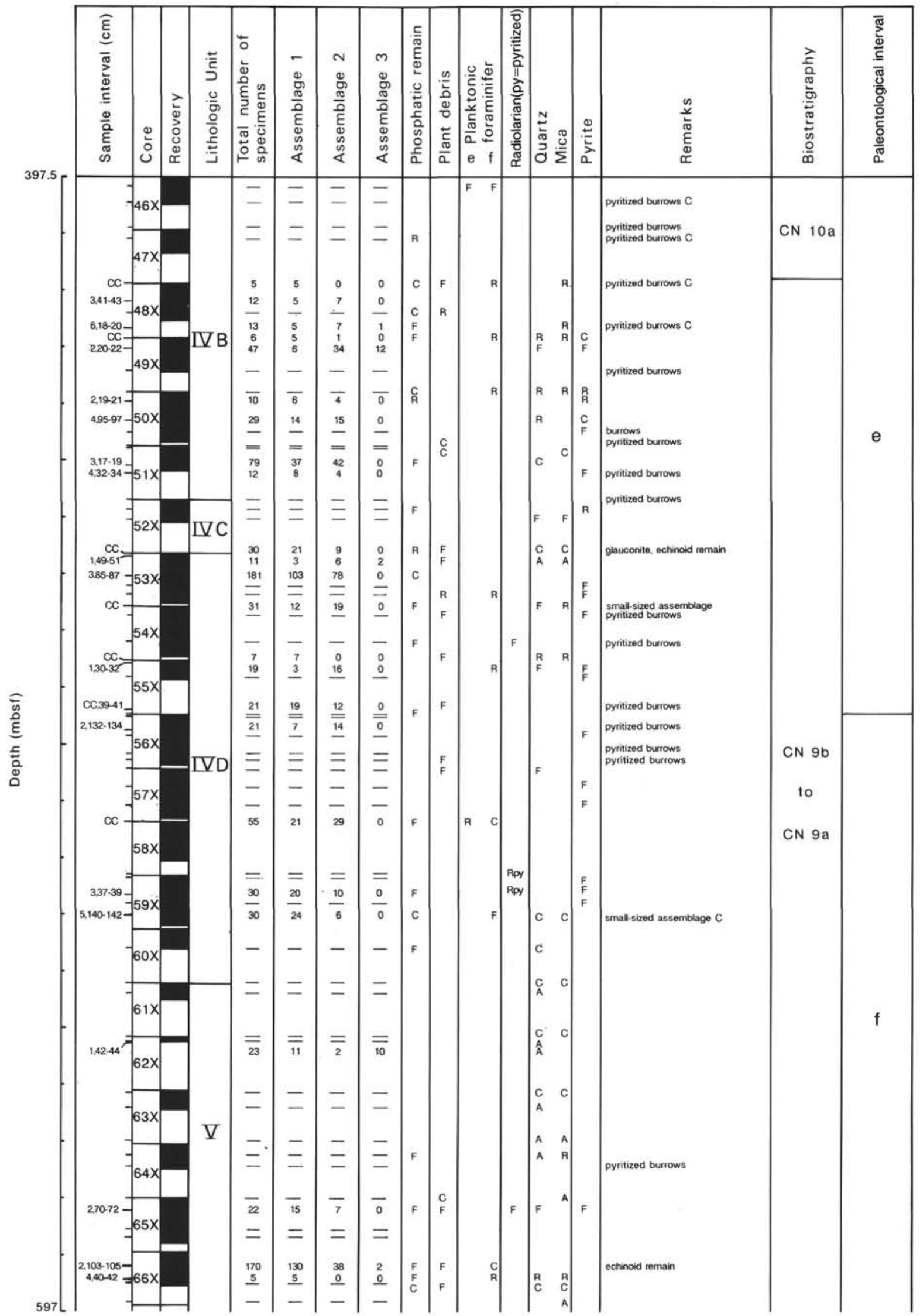

Figure 4 (continued). 


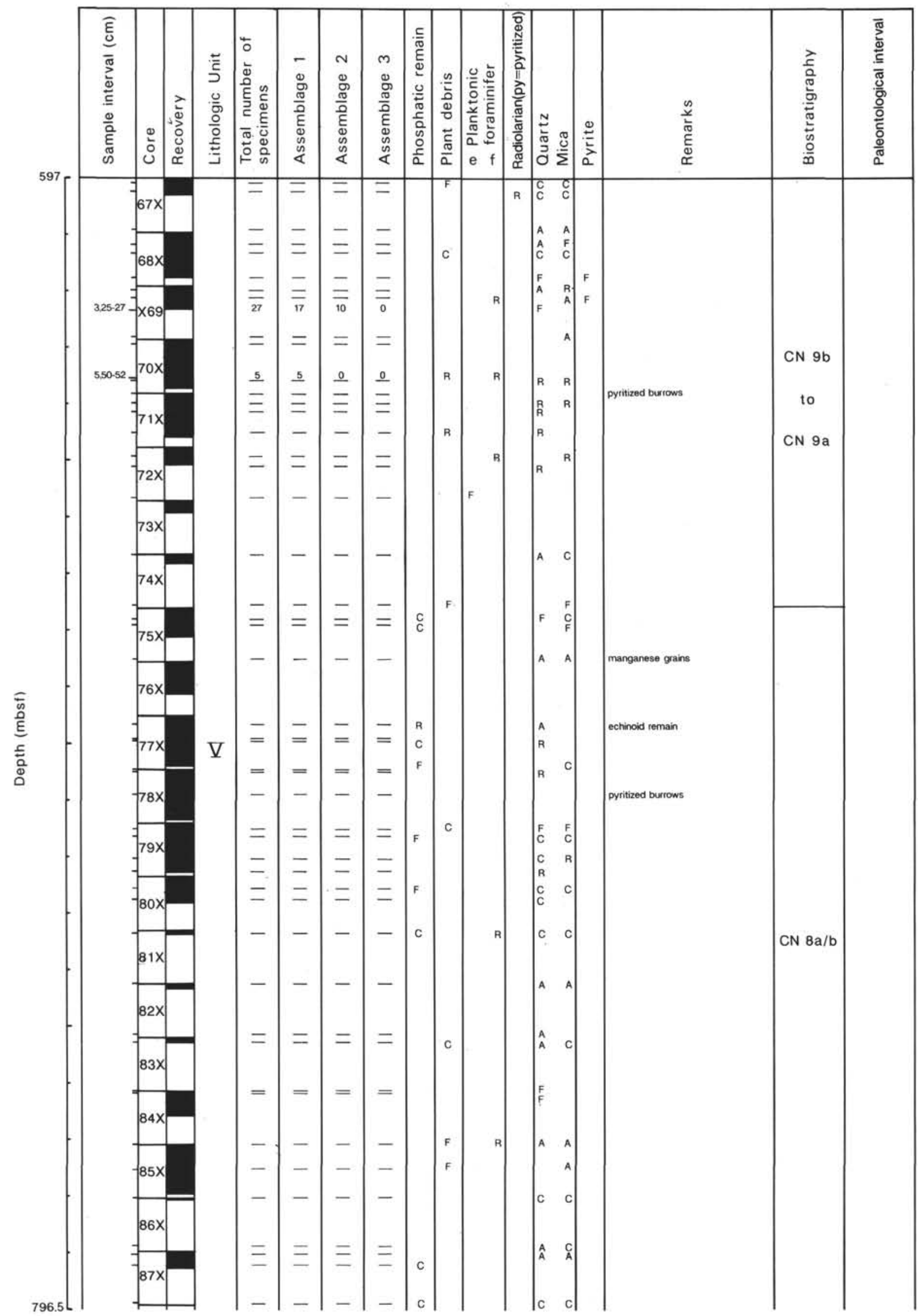

Figure 4 (continued). 


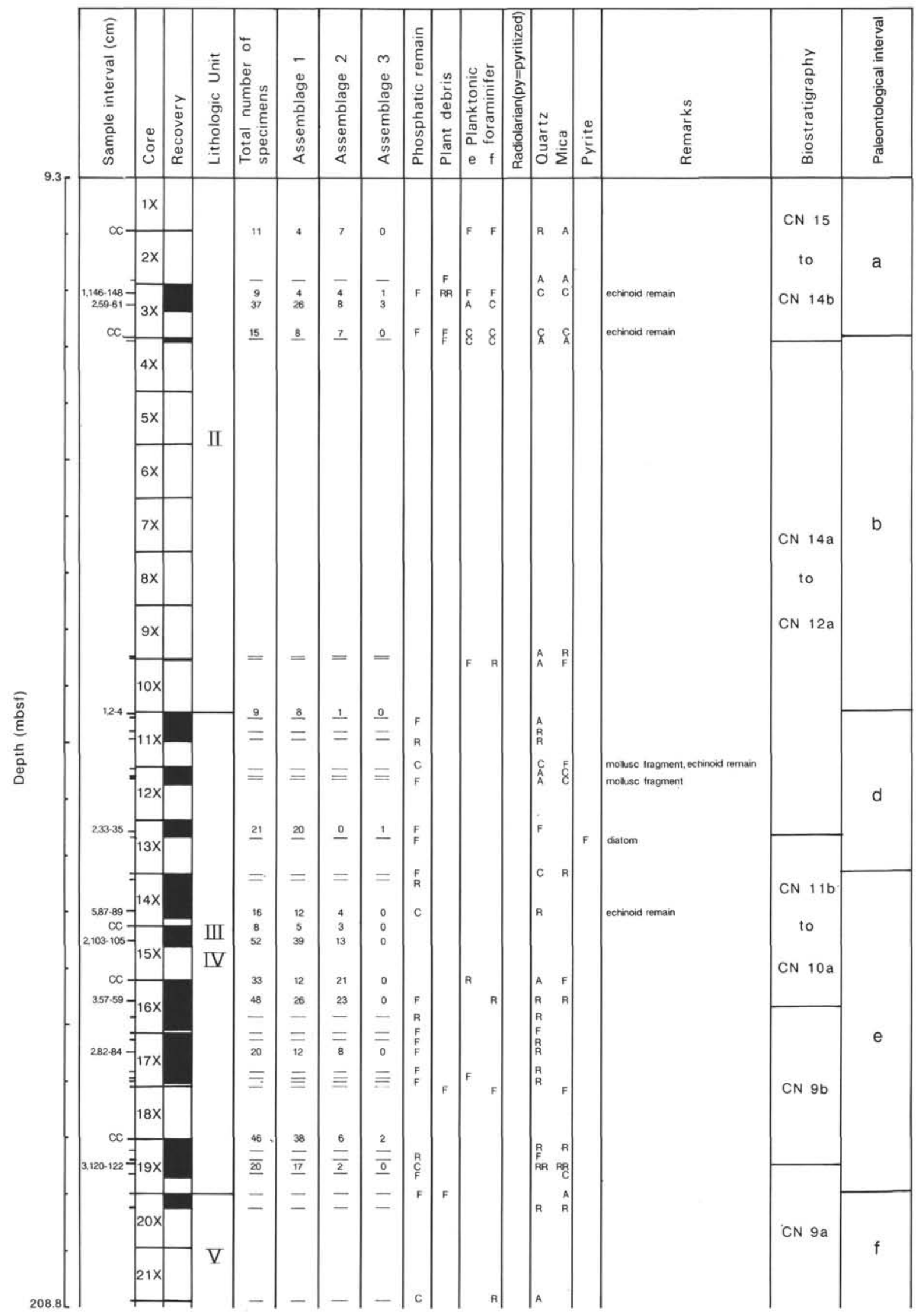

Figure 5. Synthesis of the biogenic and nonbiogenic components of Site 718. Lowest cores belonging to Unit V are not plotted. Legend: $\mathrm{A}$-abundant; $\mathrm{C}$-common; $\mathrm{F}-\mathrm{few}$; $\mathrm{R}$-rare; ech.—echnoid remains; s.s.-sponge spicule. 


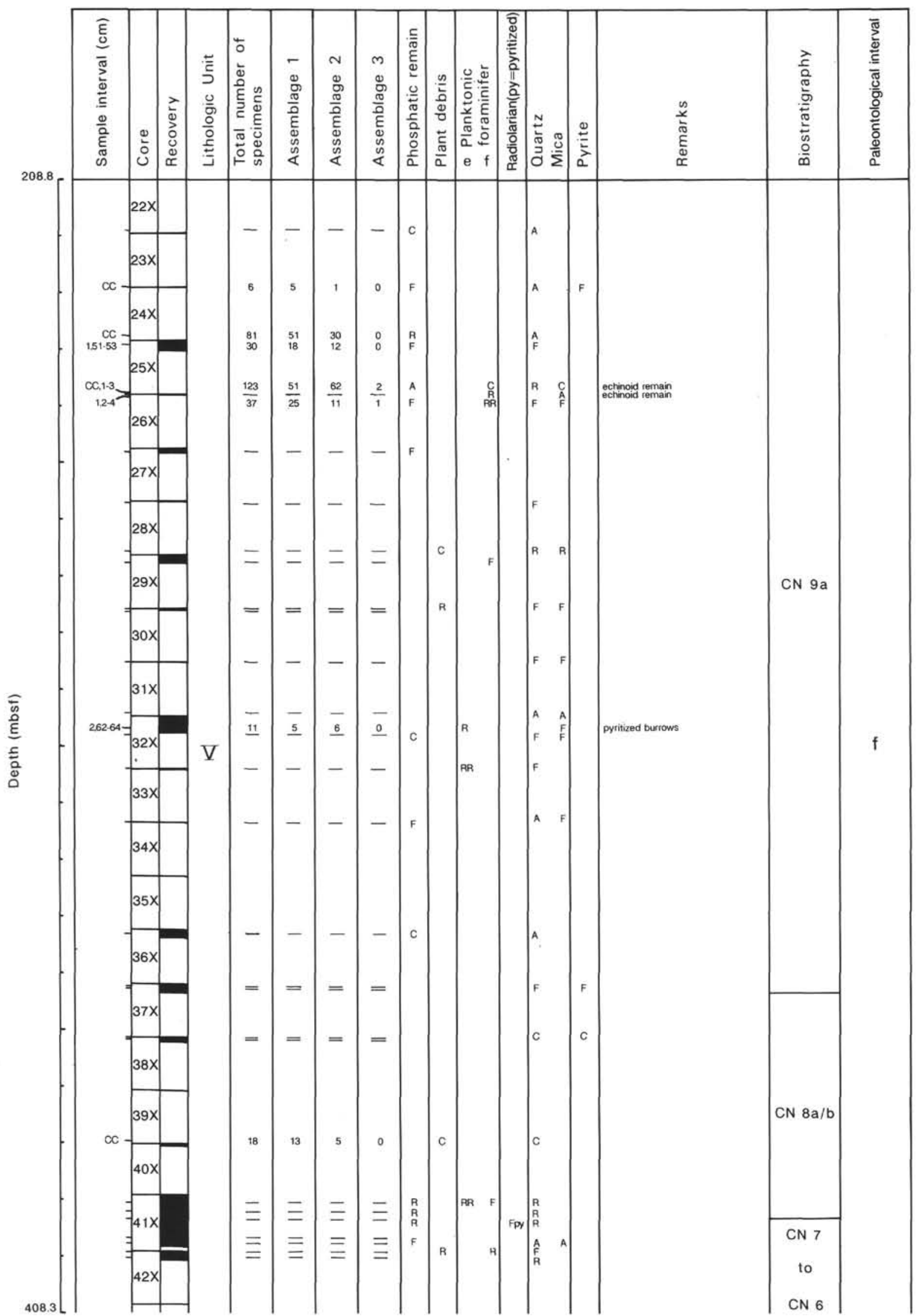

Figure 5 (continued). 


\section{Interval c: Cores 116-717C-21X to $-31 \mathrm{X}$ \\ (169.5-264.5 mbsf)}

This interval was identified in the upper part of Unit III, where some peaks of Assemblage 1 occur (116-717C-21X-1, 67-69 cm; 116-717C-22X-1, 48-50 cm; 116-717C-24X-1, 104$106 \mathrm{~cm} ; 116-717 \mathrm{C}-24 \mathrm{X}-5,20-22 \mathrm{~cm} ; 116-717 \mathrm{C}-25 \mathrm{X}-1,50-52$ $\mathrm{cm} ; 116-717 \mathrm{C}-28 \mathrm{X}-4,45-47 \mathrm{~cm})$.

\section{Interval d: Cores $116-717 \mathrm{C}-32 \mathrm{X}$ to $\mathbf{- 4 0 X}$ (264.5-350 mbsf)}

This interval encompasses the lowest part of Unit III, Subunit IVA, and the topmost part of Subunit IVB. Only three samples are fossiliferous. The maximum number of specimens observed in Sample 116-717C-34X-4, 132-134 cm is 53. Only phosphatic remains (teeth and bone fragments) are fairly common throughout.

\section{Interval e: Cores 116-717C-41X to $\mathbf{- 5 5 X}$ (350-492.5 mbsf)}

This interval encompasses most of Subunit IVB, Subunit IVC, and part of Subunit IVD. The samples richest in phosphatic remains are the poorest in foraminifers and detritic components. Pyritized concretions range throughout the interval.

\section{Interval f: Cores 116-717C-56X to $\mathbf{- 9 1 X}$ (492.5-828.2 mbsf)}

Benthic foraminifers occur very sporadically (lowest part of Units IVD and V). Common representatives of Assemblages 1 and 2 are recorded within thin intercalations ofbiogenic turbidites (Sample 116-717C-57X, CC). A rich Assemblage 1 is recorded in Sample 116-717C-66X-2, 102-104 cm.

\section{SITE 718} 5):

The paleontological intervals are recorded as follows (Fig.

\section{Interval a: Cores 116-718C-IX to $-3 \mathrm{X}$ \\ (9.3-37.8 mbsf)}

In this interval (upper part of Unit II) samples yielded a few benthic foraminifers belonging to Assemblages 1 and 2, with a maximum of 15 specimens per sample.

\section{Interval b: Cores 116-718C-4X to-10X (37.8-104.3 mbsf)}

This interval cannot be documented because there was no recovery. This part of Hole $718 \mathrm{C}$, referred to Unit II (Cochran, Stow, et al., 1989), may be correlatable with Interval b at Site 717.

\section{Interval c}

Interval $\mathrm{c}$ has not been identified at this site. In fact, no samples having paleontological features of Interval c were found at Site 718 . The green biogenic turbidites that characterize Unit III at Site 717 and 719 are in fact absent at Site 718.

\section{Interval d: Cores 116-718C-11X to $\mathbf{- 1 3 X}$ (104.3-132.8 mbsf)}

By analogy with the other two sites, it is inferred that this interval which, according to sedimentologists, belongs to Units III-IV, correlates with Interval d at Site 717 below the biogenic turbidites. It is almost barren, even though recovery was good. Only Sample 116-718C-11X-1, 2-4 cm yields some foraminifers.

\section{Interval e: Cores 116-718C-14X to $-19 \mathrm{X}$ \\ (132.8-189.8 mbsf)}

This interval also belongs to Units III-IV. Both Assemblages 1 and 2 are common and well represented. Taxa of Assemblage 3 were only observed in Core 116-718-18X. Phosphatic remains are common throughout the interval, whereas detrital material is always rare. On the basis of the total number of foraminifers larger than $150 \mu \mathrm{m}$, it is inferred that this part of the hole might correspond to most parts of Subunit IVB and Subunits IVC and IVD of Site 717.

\section{Interval f: Cores 116-718C-20X to $\mathbf{- 9 8 X}$ (189.8-935 mbsf)}

Samples 116-718C-25X, CC, and 116-718C-26X-1, 2-4 cm contain a rich fauna dominated by foraminifers of Assemblage 1 and 2. This fossiliferous horizon might correlate with that occurring in Sample 116-717C-66X-2, 103-105 cm, since both levels occur in calcareous nannofossil Zone CN9. Rare taxa of Assemblage 3 are also present (Pseudorotalia gaimardii). The sediments only yielded a few specimens in the remaining part of the sequence.

\section{SITE 719}

The benthic assemblage at Site 719 closely resembles that at Site 717 , and the same foraminifer distribution pattern is recorded (Fig. 6).

\section{Interval a: Cores $116-719 \mathrm{~A}-1 \mathrm{H}$ to $-4 \mathrm{X}$ (0-32.7 mbsf)}

This interval coincides with Unit II. The benthic assemblage is quite common throughout. Foraminifers mainly belong to Assemblages 1 and 2; Assemblage 3 occurs in a few samples.

\section{Interval b: Cores 116-719A-5X to $-15 X$ (32.7-137.2 mbsf)}

Samples from this interval, still recognizable in Unit II, are barren. Quartz grains are the main detrital component in the fraction $>150 \mu \mathrm{m}$.

\section{Interval c: Cores 116-719A-16X to $-20 \mathrm{X}$ (137.2-184.7 mbsf)}

This interval is documented in the upper part of Unit III. The richest assemblages and largest numbers of specimens are recorded from this interval. Species of Assemblage 1 are the most abundant (Samples 116-719A-16X-4, 16-18 cm; 116719A-16X-5, 68-70 cm; 116-719A-17X-5, 87-89 cm), but Assemblage 2 is also common. Foraminifers of Assemblage 3 occur sporadically except in Sample 116-719A-16X-4, 16-18 $\mathrm{cm}$.

\section{Interval d: Cores 116-719A-21X to $-27 \mathrm{X}$}

(184.7-251.2 mbsf)

This short interval recognizable in Unit III, Subunit IVA, and the topmost part of Subunits IVB-IVD is remarkably different from the overlying one. The benthic assemblage decreases in abundance and the examined samples contain rare specimens. The richest fauna is observed in Sample 116-719A-22X-3, 53-55 cm (41 specimens, Assemblages 1, 2, and 3). Pyritized concretions are frequent.

\section{Interval e: Cores 116-719A-28X to $\mathbf{- 3 8 X}$ (251.2-355.7 mbsf)}

This interval is recorded in Subunits IVB-IVD. Benthic foraminifers are generally rather well represented. The most 


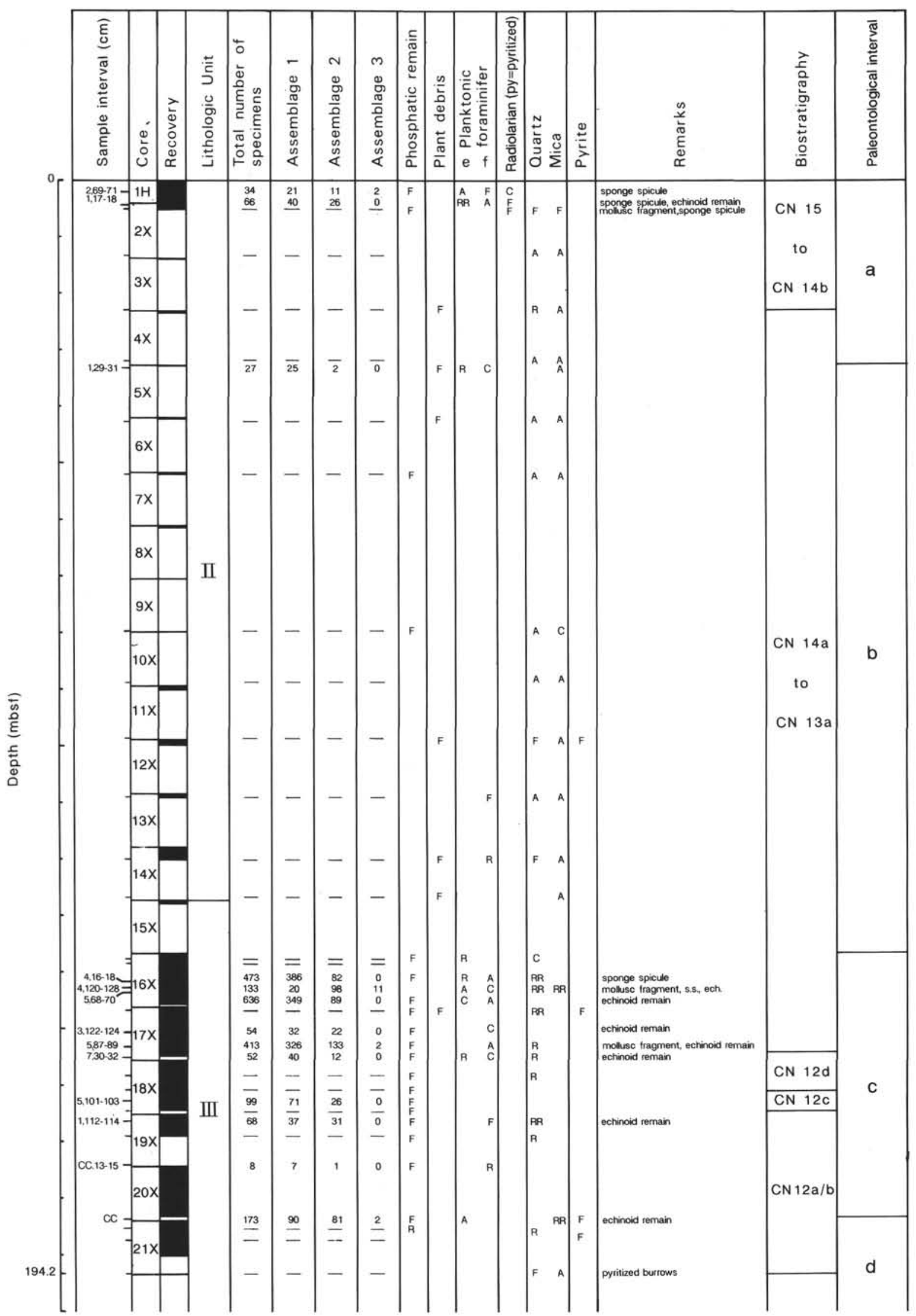

Figure 6. Synthesis of the biogenic and nonbiogenic components of Site 719. Lowest cores belonging to Unit V are not plotted. A-abundant; $\mathrm{C}$-common; $\mathrm{F}$-few; R-rare; ech.-echnoid remains; s.s.—sponge spicule. 


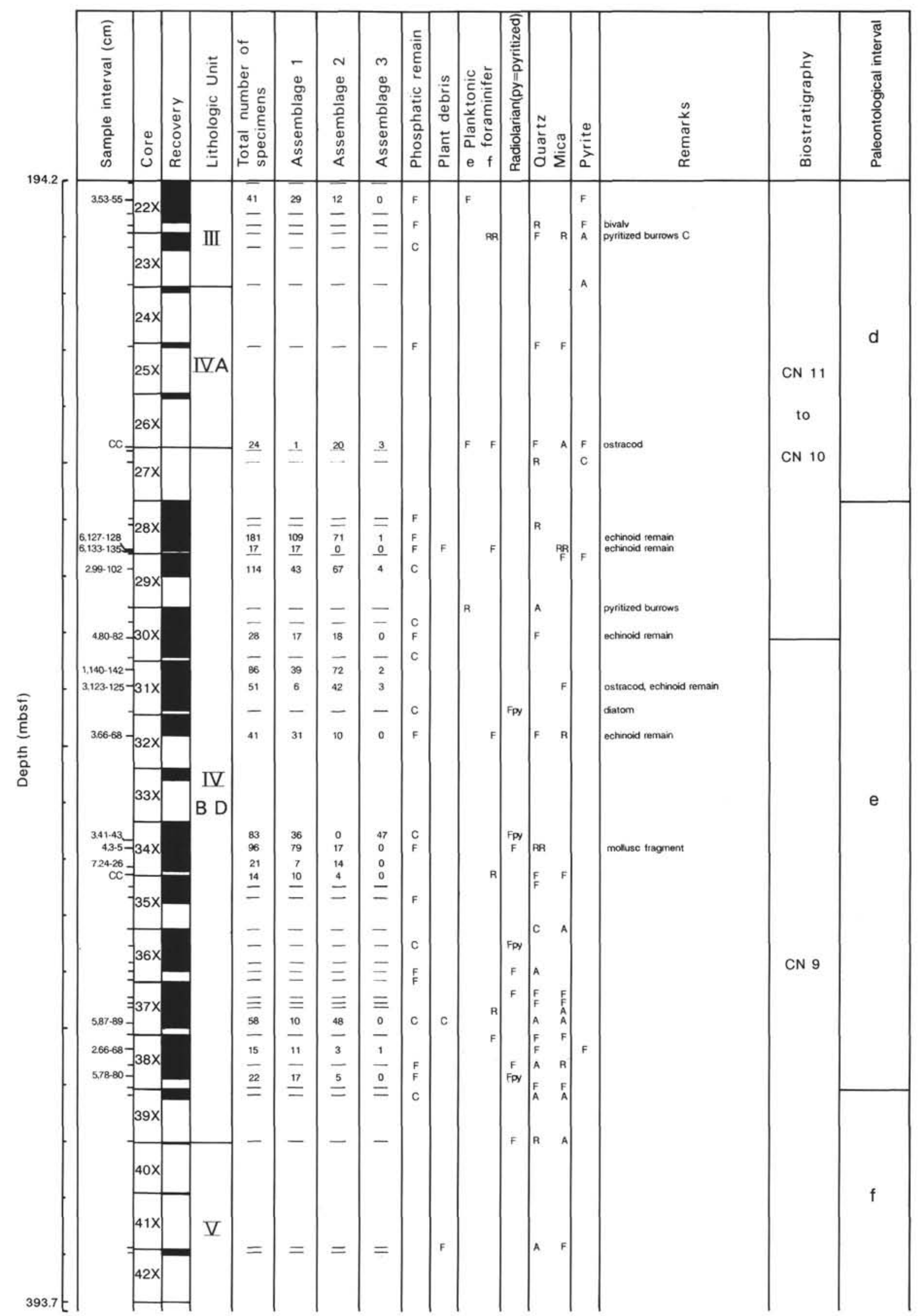

Figure 6 (continued). 
common species belong to Assemblages 1 and 2, but some taxa of Assemblage 3 also occur.

\section{Interval f: Cores 116-719A-39X to $-49 \mathrm{X}$ (355.7-460.2 mbsf)}

This interval is recognizable in Unit V. Most of the samples are barren or contain very few specimens of the three assemblages.

\section{CORRELATION BETWEEN FORAMINIFER DISTRIBUTION PATTERN AND LITHOSTRATIGRAPHIC UNITS}

Paleontological Intervals a to $\mathrm{f}$ related to the benthic foraminifer pattern were plotted against the lithostratigraphic units, the calcareous nannofossil biostratigraphy, and biochronology (Fig. 7). Good correlation was found between the paleontological intervals at the three sites and also with lithostratigraphic and biostratigraphic units.

\section{Intervals $\mathbf{a}$ and $\mathbf{b}$}

These intervals are correlatable with Unit II at all three sites. Their thickness decreases from Site 717 toward Site 718. They extend from Cores 116-717B-1H to 116-717C-20X in Site 717 (interval $160 \mathrm{~m}$ thick), from Cores $116-719 \mathrm{~A}-1 \mathrm{H}$ to $-15 \mathrm{X}$ at Site 719 (interval $137 \mathrm{~m}$ thick) and from Cores 116-718C-1X to $-10 \mathrm{X}$ in Site 718 (interval $104 \mathrm{~m}$ thick). The lower boundary is younger than $0.93 \mathrm{Ma}$ (top of the small Gephyrocapsa Acme) in Sites 717 and 719 . At Site 718 age cannot be determined, because the bioevent is not recorded.

\section{Interval c}

This interval, which coincides with the biogenic turbiditic sequence, is clearly recognizable at Sites 717 and 719 from Cores 116-717C-21X to -31X (interval $95 \mathrm{~m}$ thick) and from Cores 116-719A-16X to -20X (interval $47.5 \mathrm{~m}$ thick), respectively. Because interval $\mathrm{c}$ was not detected at Site 718 , it is inferred that the upper part of the Unit III was not deposited here. Recognition within this interval of the FO of Gephyrocapsa oceanica s.1. (Gartner, this volume) seems to exclude the possibility that the biogenic turbidites were eroded after deposition.

\section{Interval d}

This interval encompasses the lower part of Unit III, Subunit IVA, and the topmost part of Subunit IVB at Sites 717, and 719, and extends from Cores 116-717C-32X to $-40 \mathrm{X}$ (interval $85 \mathrm{~m}$ thick) and from Core $116-719 \mathrm{~A}-21 \mathrm{X}$ to $-27 \mathrm{X}$ (interval $66.5 \mathrm{~m}$ thick). The LO of Sphenolithus abies and Reticulofenestra pseudoumbilica occur within this interval at both sites (Gartner, this volume). At Site 718 the interval is much thinner (about $30 \mathrm{~m}$ ), and extends from Cores 116-718C$11 \mathrm{X}$ to-13X (upper part of Units III-IV).

\section{Interval e}

This interval encompasses most of Subunits IVB, IVC, and the topmost part of Subunit IVD in Site 717. At Site 719 it is correlatable with most of Subunits IVB-IVD. At Site 718 it extends from Cores 116-718C-14X to $-19 \mathrm{X}$, encompassing the lower part of Units III-IV. The LO of Discoaster quinqueramus falls within this interval in the three sites (Gartner, this volume).

\section{Interval f}

This interval, which extends down to the bottom in all three sites, encompasses the lower part of Units IVD and V in Site 717, Unit V at Site 719, and, at least, part of Unit VA at
Site 718 , without any change in the benthic foraminifer assemblages.

\section{CONCLUDING REMARKS}

The data from Sites 717, 718, and 719 cannot easily be used for significant conclusions. The benthic foraminifers are mostly redeposited and diluted in the turbiditic sediments that dominate the sequences.

Three types of assemblages based on benthic distribution content were identified, indicative of three different bathymetric environments; thus, the possible source area of the sediments may be suggested.

Assemblage 1, indicative of cold and deep-water masses, is associated with AABW. This assemblage may represent autochthonous deep fauna, because it is the only one that becomes very abundant and dominant in some horizons. Assemblage 2 groups taxa that are indicative of outer shelf to lower bathyal environments. The assemblage itself may be well represented, but its taxa are never abundant.

Assemblage 3 comprises shallow-water taxa whose occurrence in the turbidites of the three sites testifies an extensive transport from the northern inner shelf.

The benthic foraminiferal distribution patterns showed a succession of six intervals (a to f) correlatable between all three sites. Such patterns indicate that Interval c, corresponding to the biogenic turbidites occurring only at Sites 717 and 719 , is characterized by two types of benthic foraminifer assemblage: the first, which is present throughout the biogenic turbidite sequence, mostly consists of a small $(<150 \mu \mathrm{m})$, well-sorted, well-preserved, rich and abundant assemblage. The second, occurring at some thin horizons at the top of bioturbidite cycles, mostly consists of species, larger than 150 $\mu \mathrm{m}$, of Assemblage 1. Interval c decreases in thickness from north to south, from $95 \mathrm{~m}$ at Site $717,47.5 \mathrm{~m}$ at Site 719, and $0 \mathrm{~m}$ at Site 718. The lowest occurrence of $G$. oceanica occurs within Interval c at Sites 717 and 719, whereas the same event occurs within Interval d at Site 718 . Therefore, during the same time interval, sedimentation at Site 718 was different from that at Sites 717 and 719 . Most probably the uplifted faulted block formed a barrier that prevented the arrival of bioturbidites at Site 718 .

The source area of the bioturbidites is probably an area not too far to the north, considering the good degree of preservation of the foraminifer tests. Although one of the possible source areas may be located in the surrounding seamounts, the Afanasiy Nikitin Seamounts seem to be excluded, as they are located south of Site 718 .

The bioturbidite "event" probably records a period of climatic deterioration that caused shallowing of the sea level (lowstand; Haq et al., 1987) and detachment of the bioturbidites. This suggestion is supported by the abundance of Assemblage 1, possibly related to intensification of AABW. According to the calcareous nannofossil biochronology ( $\mathrm{LO}$ of Discoaster surculus and Discoaster asymmetricus), the lowest peak of Assemblage 1 corresponds to the climatic deterioration that occurred close to the Gauss/Matuyama boundary $(2.42 \mathrm{Ma})$ during the late Pliocene. The highest peaks observed above the FO of Gephyrocapsa oceanica $(1.59 \mathrm{Ma})$ and the end of the small Gephyrocapsa Acme ( $0.93 \mathrm{Ma})$ may correspond to the severe climatic deterioration that occurred near the base or within the glacial Pleistocene (Shackleton et al., 1984).

\section{ACKNOWLEDGMENTS}

We thank the Ocean Drilling Program for inviting us to participate on Leg 116 aboard the JOIDES Resolution. We are 


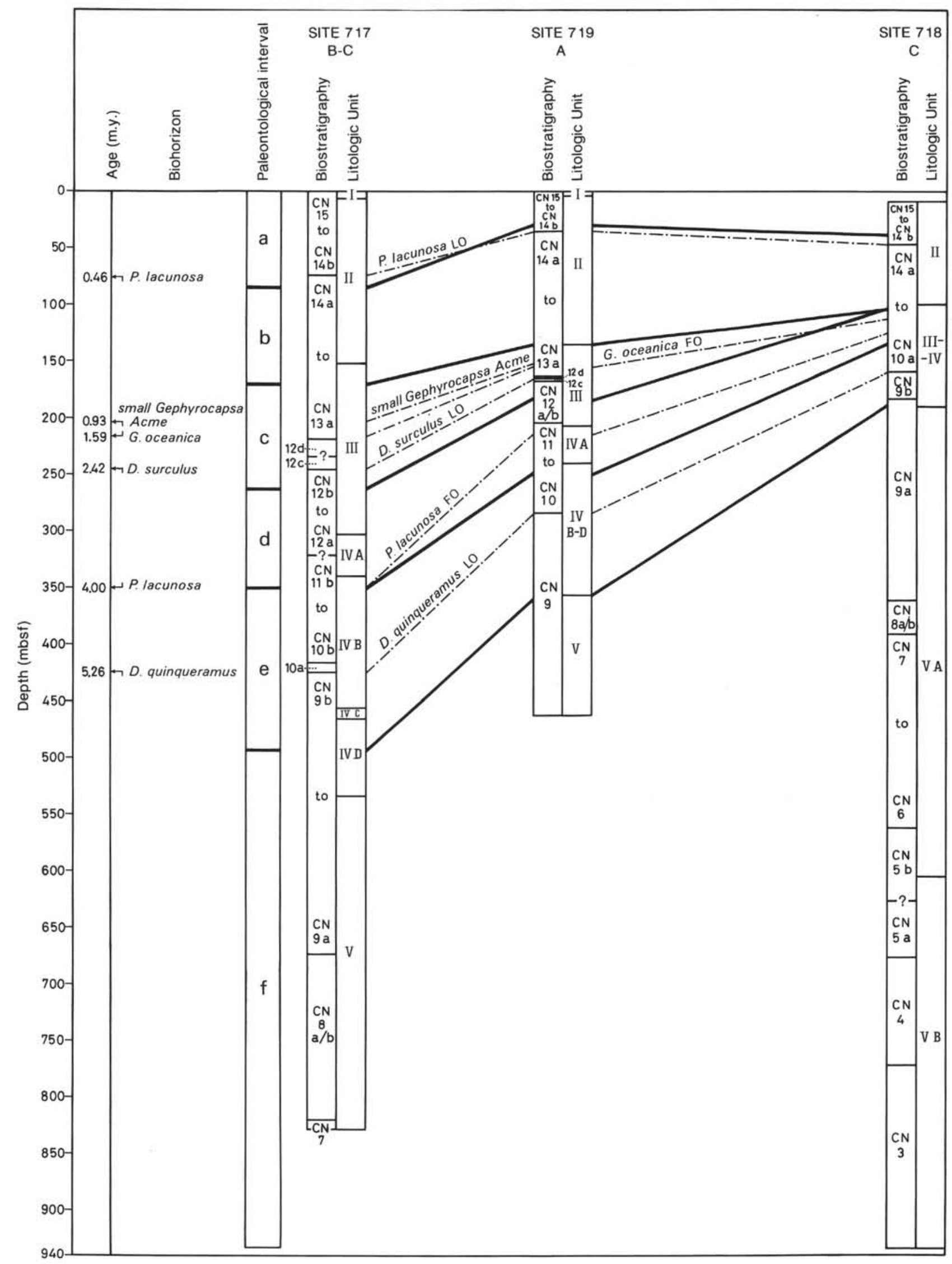

Figure 7. Correlation between benthic foraminifer pattern intervals, lithostratigraphy, biostratigraphy, and biochronology. Heavy line marks the paleontological interval boundaries; dashed line marks calcareous nannofossil events. 
grateful to Sandra Gaboardi, Edwige Masini, Fulvio Todesco, Claudio Brogiato, and Bruno Rampazzo for their generous assistance in the various phases of work preparation. This study was supported by the Consiglio Nazionale delle Ricerche (CNR) and Ministero Pubblica Istruzione (MPI) of Italy.

\section{REFERENCES}

Baldauf, J. G., Thomas, E., Clement, B., Takayama, T., Weaver, P.P.E., Backman, J., Jenkins, G., Mudie, P. J., and WestbergSmith, M. J., 1987. Magnetostratigraphic and biostratigraphic synthesis, Deep Sea Drilling Project Leg 94. In Ruddiman, W. F., Kidd, R. B., et al., Init. Repts. DSDP, 94, (Pt. 2): Washington (U.S. Govt. Printing Office), 1159-1205.

Bandy, O. L., 1968. Paleoclimatology and Neogene planktonic foraminiferal zonation. Committee on Mediterranean Neogene Stratigraphy Proceedings of the fourth Session, Bologna, 1967. G. Geol. 35:277-290.

Boersma, A., 1984. Oligocene and other Tertiary benthic foraminifers from a depth traverse down Walvis Ridge, Deep Sea Drilling Project Leg 74, Southeast Atlantic. In Hay, W. W., Sibuet, J.-C., et al., Init. Repts. DSDP, 75: Washington (U.S. Govt. Printing Office), 1273-1303.

Boltovskoy, E., 1977. Neogene deep water benthonic foraminifera of the Indian Ocean. In Heirtzler, J. R., Bolli, H. M., Davies, T. A., Saunders, J. B., and Sclater, J. G. (Eds.), Indian Ocean Geology and Biostratigraphy: Washington (Am. Geophys. Union), 599-616. 1980. On the benthonic bathyal-zone foraminifera as stratigraphic guide fossils. J. Foraminiferal Res., 10:163-172.

Boltovskoy, E., and Wright, R., 1976. Recent Foraminifera: The Hague (W. Junk).

Burke, S. C., 1981. Recent benthic foraminifera of the Ontong Java plateau. J. Foraminiferal Res., 11:1-19.

Cochran, J. R., Stow, D.A.V., et al., 1989. Proc. ODP, Init. Repts., 116: College Station, TX (Ocean Drilling Program).

Corliss, B. H., 1979a. Recent deep-sea benthonic foraminiferal distributions in the southeast Indian Ocean: inferred bottom-water routes and ecological implications. Mar. Geol., 31:115-138.

B. H., 1979b. Taxonomy of Recent deep-sea benthonic foraminifera from the southeast Indian Ocean. Micropaleontology, 25:1-19.

1983. Distribution of Holocene deep-sea benthonic foraminifera in the southwest Indian Ocean. Deep-Sea Res., 30:95117.

Gartner, S., Chen, M. P., and Stanton, R. J., 1983. Late Neogene nannofossil biostratigraphy and paleoceanography of the northeastern Gulf of Mexico and adjacent areas. Mar. Micropaleontol., $8: 17-50$.

Haq, B. U., Hardenbol, J., and Vail, P. R., 1987. Chronology of fluctuating sea levels since the Triassic. Science, 235:1156-1167.

Lohmann, G. P., 1978. Abyssal benthonic foraminifera as hydrographic indicators in the western South Atlantic Ocean. J. Foraminiferal Res., 8:6-34.

Mead, G. A., 1985. Recent benthic foraminifera in the polar front region of the southwest Atlantic. Micropaleontology, 31:221-248.

Murray, J. W., 1973. Distribution and Ecology of Living Benthic Foraminiferids: New York (Crane and Russak).

Peterson, L. C., 1984. Recent abyssal benthic foraminiferal biofacies of the eastern equatorial Indian Ocean. Mar. Micropaleontol., $8: 479-519$.

Phleger, F. B., 1960. Ecology and Distribution of Recent foraminifera: Baltimore (The Johns Hopkins Press).

Phleger, F. B., Parker, F. L., and Peirson, J. F., 1953. North Atlantic foraminifera. Rep. Swed. Deep-Sea Exped., 1947-1948, 7:1-121.

Resig, J. M., 1981. Biogeography of benthic foraminifera of the northern Nazca plate and adjacent continental margin. Geol. Soc. Am. Mem., 154:619-665.

Rio, D., Backman, J., Raffi, I., in press. Calcareous nannofossil biochronology and the Pliocene/Pleistocene boundary. The Neogene/Quaternary Boundary. Final Rep. IGCP Project, 41.

Rögl, F., 1976. Late Cretaceous to Pleistocene foraminifera from the Southeast Pacific Basin, DSDP Leg 35. In Hollister, C. D.,
Craddock, C., et al., Init. Repts. DSDP, 35: Washington (U.S. Govt. Printing Office), 539-555.

Ruggieri, G., and Selli, R., 1950. II Pliocene e Postpliocene dell'Emilia. G. Geol., 20:1-14.

Shackleton, N. J., and Cita, M. B., 1979. Oxygen and carbon isotope stratigraphy of benthic foraminifers at Site 397: detailed history of climatic change during the late Neogene. In von Rad, U., Ryan, W.B.F., et al., Init. Repts. DSDP, 47: Washington (U.S. Govt. Printing Office), 433-445.

Shackleton, N. J., Backman, J., Zimmerman, H., Kent, D. V., Hall, M. A., Roberts, D. G., Schnitker, D., Baldauf, J., Desprairies, A., Homrighausen, R., Huddlestun, P., Keene, J. B., Kaltenback, A. J., Krumsiek, K.A.O., Morton, A. C., Murray, J. W., and Westberg-Smith, J., 1984. Oxygen isotope calibration of the onset of ice-rafting in DSDP Site 552A: history of glaciation in the North Atlantic region. Nature, 307:620-623.

Shipboard Scientific Party, 1989a. Site 717: Bengal Fan. In Cochran, J. R., Stow, D.A.V., et al., Proc. ODP, Init. Repts., 116: College Station, TX (Ocean Drilling Program), 45-89.

1989b. Site 718: Bengal Fan. In Cochran, J. R., Stow,

D.A.V., et al., Proc. ODP, Init. Repts., 116: College Station, TX (Ocean Drilling Program), 91-154.

1989c. Site 719: Bengal Fan. In Cochran, J. R., Stow, D.A.V., et al., Proc. ODP, Init. Repts., 116: College Station, TX (Ocean Drilling Program), 155-196.

Stow, D.A.V., Cochran, J. R., and ODP Leg 116 Shipboard Scientific Party, 1989. The Bengal Fan: some preliminary results from ODP drilling. Geo-Mar. Lett., 9:1-10.

Thomas, E., 1985. Late Eocene to Recent deep-sea benthic foraminifers from the central equatorial Pacific Ocean. In Mayer, L., Theyer, F., et al., Init. Repts. DSDP, 85: Washington (U.S. Govt. Printing Office), 655-694.

1986. Changes in composition of Neogene benthic foraminiferal faunas in equatorial Pacific and North Atlantic. Palaeogeogr., Palaeoclimatol., Palaeoecol., 53:47-49.

Thunnell, R. C., and Williams, D. F., 1983. The stepwise development of Pliocene-Pleistocene paleoclimatic and paleoceanographic conditions in the Mediterranean: oxygen isotope studies of DSDP Site 125 and 132. Utrecht Micropaleontol. Bull., 30:111-127.

Trevisan, L., and Di Napoli, E., 1938. Tirreniano, Siciliano e Calabriano nella Sicilia sud-occidentale. G. Sc. Nat. Econ. Palermo, 39.

van Morkhoven, F.P.C.M., Berggren, W. A., and Edwards, A. S., 1986. Cenozoic cosmopolitan deep-water benthic foraminifera. Bull. Cent. Rech. Explor.-Prod. Elf-Aquitaine, 11.

Williams, D. F., Thunnell, R. C., Tappa, E., Rio, D., and Raffi, I., 1988. Chronology of the Pleistocene oxygen isotope record: $0-1.88$ m.y.B.P. Paleogeogr., Paleoclimatol., Paleoecol., 64:221-240.

Woodruff, F., 1985. Changes in Miocene deep-sea benthic foraminiferal distribution in the Pacific Ocean: relationship to paleoceanography. In Kennett, J. P. (Ed.), The Miocene Ocean: Paleoceanography and Biogeography. Mem. Geol. Soc. Am., 163:131-176.

Woodruff, F., and Douglas, R. G., 1981. Response of deep-sea benthic foraminifera to Miocene paleoclimatic events, DSDP Site 289. Mar. Micropaleontol., 6:617-632.

Date of initial receipt: 29 June 1989

Date of acceptance: 17 January 1990

Ms 116B-124

\section{APPENDIX}

Benthic foraminifers of Sites 717,718 , and 719 were distinguished at a specific level when they were common and/or recurrent; they were grouped when they were scattered and random. They were distinguished as follows:

$$
\text { Assemblage } 1
$$

Epistominella exigua (Brady)

Globocassidulina subglobosa (Brady)

Nuttallides umbonifera (Cushman)

Oridorsalis umbonatus (Reuss) includes the type species, $O$. umbonatus stellatus (Silvestri), and O. tener (Brady).

Planulina wuellerstorfi (Schwager)

Pullenia bulloides (d'Orbigny) 


\section{Assemblage 2}

Anomalinoides spp. includes $A$. alazanensis (Nuttall), A. rubiginosus (Cushman), A. granosus (Hantken), A. semicribratus (Beckmann), and some undetermined forms.

Bolivinids includes Bolivina pseudoplicata (Heron-Allen and Earland), B. robusta (Brady), and Bolivina spp., Brizalina alata (Seguenza), B. pygmaea (Brady), B. spissa (Cushman), and Brizalina spp., Rectobolivina sp., Sigmavirgulina tortuosa (Brady), Bolivinella sp., Bolivinita sp., and Suggrunda sp. Bolivinita quadrilatera (Schwager)

Bulimina marginata (d'Orbigny)

Buliminids includes $B$. aculeata (d'Orbigny), B. elongata (d'Orbigny), B. rostrata (Brady), and Bulimina spp., Globobulimina pupoides (d'Orbigny), G. pyrula (d'Orbigny), and Globobulimina spp.

Cassidulina group includes C. neocarinata (Thalmann), C. crassa (d'Orbigny), C. oblonga (Reuss), C. reniforme (Norvang), and $C$. laevigata (d'Orbigny).

Cibicidoides spp, includes C. kullembergi (Parker), C. pachyderma (Rzehak), C. perlucidus (Nuttall), C. cicatricosus (Schwager), C. mundulus (Brady, Parker, and Jones), C. floridanus (Cushman), Cibicides refulgens (de Montfort), and some undetermined forms.

Eggerella bradyi (Cushman)

Ehrenbergina hystrix (Brady)

Eponides tumidulus (Brady) includes typical and atypical forms.

Fursenkoina spp. includes F. tenuis (Seguenza), and some other undetermined forms.

Gavelinopsis lobatulus (Parr)

Gyroidinoides neosoldanii (Brotzen)

Gyroidinoides altiformis (Stewart and Stewart)

Gyroidinoides umbonatus (Silvestri), group includes typical specimens, and similar forms.

Gyroidinoides laevigatus (d'Orbigny) group includes typical specimens and similar forms.

Gyroidinoides spp. groups the following species: G. lamarckiana
(d'Orbigny), G. longispira (Tedeschi and Zanmatti), and Gyroidina acuta (Boomgaart).

Hoeglundina elegans (d'Orbigny)

Hyalinea balthica (Schroeter)

Lagena group includes the genera Lagena, Oolina, and Fissurina.

Laticarinina pauperata (Parker and Jones)

Melonis nicobarensis (Cushman) also groups M. padanum (Perconig), M. barleanum (Williamson), M. affinis (Reuss), and Nonion havanense (Cushman and Bermudez).

Melonis pompilioides (Fichtel and Moll)

Plectofrondicularia spp. includes $P$. striata (d'Orbigny) and $P$. floridana (Cushman).

Pullenia group includes $P$. salisburyi (Stewart and Stewart), $P$. quinqueloba (Reuss), P. quadriloba (Reuss), and Pullenia sp.

Pyrgo spp. includes P. murrhina (Schwager), and P. oblonga (d'Orbigny).

Reussella spinulosa (Reuss)

Sphaeroidina bulloides (d'Orbigny)

Stainforthia spp. includes $S$. complanata (Egger) and $S$. concava (Höglund).

Uvigerinids includes $U$. peregrina Cushman, $U$. proboscidea (Schwager), U. spp., Trifarina sp., Hopkinsina sp., and Stilostomella sp.

Ammonia beccarii (Linné)

Assemblage 3

Elphidium spp. includes different species and Protelphidium cf. granosum (d'Orbigny).

Florilus boueanus (d'Orbigny) also includes F. labradoricus (Dawson).

Hanzawaia boueana (d’Orbigny)

Miliolids includes Quinqueloculina, Scutuloris, Sigmoilopsis, and Triloculina genera.

Nonionella spp. includes $N$. pulchella (Hada) and Nonionella sp.

Rosalina globularis (d'Orbigny).

Pararotalia spp. includes Pseudorotalia gaimardii (d'Orbigny), and Pararotalia sp.

Textularia group includes Textularia sp., and Siphotextularia sp. 